\title{
The Impacts of Transportation Infrastructure on Sustainable Development: Emerging Trends and Challenges
}

\author{
Luqi Wang ${ }^{1}$, Xiaolong Xue ${ }^{1,2}$, Zebin Zhao ${ }^{1, *}$ and Zeyu Wang ${ }^{2}$ \\ 1 School of Management, Harbin Institute of Technology, Harbin 150001, China; luqiwang@hit.edu.cn (L.W.); \\ xlxue@hit.edu.cn (X.X.) \\ 2 School of Management, Guangzhou University, Guangzhou 510006, China; wangzeyu@gzhu.edu.cn \\ * Correspondence: zhaozebin@hit.edu.cn; Tel.: +86-186-4601-1919
}

Received: 13 April 2018; Accepted: 31 May 2018; Published: 5 June 2018

\begin{abstract}
Transportation infrastructure has an enormous impact on sustainable development. To identify multiple impacts of transportation infrastructure and show emerging trends and challenges, this paper presents a scientometric review based on 2543 published articles from 2000 to 2017 through co-author, co-occurring and co-citation analysis. In addition, the hierarchy of key concepts was analyzed to show emerging research objects, methods and levels according to the clustering information, which includes title, keyword and abstract. The results expressed by visual graphs compared high-impact authors, collaborative relationships among institutions in developed and developing countries. In addition, representative research issues related to the economy, society and environment were identified such as cost overrun, spatial economy, prioritizing structure, local development and land value. Additionally, two future directions, integrated research of various effects and structure analysis of transportation network, are recommended. The findings of this study provide researchers and practitioners with an in-depth understanding of transportation infrastructure's impacts on sustainable development by visual expression.
\end{abstract}

Keywords: transportation infrastructure; sustainable development; scientometric analysis; visual analysis; collaboration network

\section{Introduction}

Transportation infrastructure, as a complex network, connects cities and accommodates human activities coupling the social, economic and environmental systems with the urbanization and population growth. Additionally, the transportation network contributes to the socioeconomic development and the increased quality of life through generating inter- or intra-city connections during urbanization [1,2]. In addition, goals such as low-carbon, resilient and sustainable development should not be ignored when the transportation network is expanded [3]. In detail, transportation infrastructure among cities leads to urban aggregation and diffusion, greatly boosting the regional and national economic development $[4,5]$. However, the irrational planning of transportation infrastructure also generates negative effects, such as the ecological destruction, increased traffic accidents, climate change, $\mathrm{CO}_{2}$ emissions and lower transport efficiency [6-11]. Therefore, it is necessary to identify multiple impacts of transportation infrastructure from existing studies.

Recently, the impact of transportation infrastructure has been a hot topic, and the economic effect of transportation infrastructure has been receiving more attention and debate [12] because of the pursuit to direct economic growth of both regions and sectors [13]. To review multiple impacts of transportation infrastructure, scientometric studies have been used to analyze the literature and 
reveal trends in some specific topics such as transport phenomenon [14] and public transport [15]. However, in the field of transportation, existing scientometric studies mainly focus on statistical results, lacking the exploration of visual and network structure analysis. Therefore, this paper analyzed the co-author, co-occurring and co-citation network based on the collected literature expressed by visual graphs. The software Citespace was used to build the author and literature collaboration network and the co-citation analysis based on the expanded data from the citation dimension. This expansion increases the potential data source and improves the accuracy of review analysis. More importantly, scientometric study based on network visualization is an effective way to identify representative researches in the network structure and find the phenomenon and regularity compared with traditional literature analysis.

In this paper, we present a scientometric and systematic review that explores the literature related to the impact of transportation infrastructure in the database of Web of Science from 2000 to 2017. The aims of this study are identifying the research trends in the field of the transportation infrastructure and finding the hot research topics through the visualization map built by the literature. This paper is divided into three main parts. Section 2 introduces the basic concepts, characteristics and multiple impacts of the transportation. Theoretical analysis provides an in-depth understanding of the impact mechanism of transportation infrastructure according to existing studies. Section 3 introduces the scientometric method in this paper. This method provides a means of visualization to identify the information in the map based on the software Citespace. Section 4 analyzes the scientometric results, including co-author, co-occurring and co-citation analysis. Finally, according to the identified cluster data, this paper systematically summarizes representative studies and important categories related to the effect of transportation infrastructure. Multiple analysis greatly increases the accuracy of the results.

\section{Transportation Infrastructure}

\subsection{The Definition and Characteristics of Transportation Infrastructure}

As one of the main urban elements, transportation infrastructures such as roads, highways, railways, airports, bridges, waterways, canals and terminals play important roles in the transmission of materials and the flow of population during urban agglomeration and diffusion [16-18]. Just as stated in the definition given by OECD (2013), transportation infrastructure is a critical ingredient in the economic development at all levels of the income, supporting personal well-being and economic growth. From the perspective of function, transportation infrastructure is a kind of large-scale public work which has the importation influence on countries' politics, economy, society, science, technology development, environmental protection, public health and national security. Besides, as a part of transportation system apart from the operating system and transport vehicles, the plan and construction of transportation infrastructure are complex. Grimsey and Lewis think it is easier and more meaningful to identify infrastructure than to define the infrastructure, and the key to identifying the infrastructure is indicating its characteristics [19]. For example, during construction, it has characteristics of large investment scale, long construction period, complicated risk, and many stakeholders [20].

Transportation infrastructure has the fundamental features of general infrastructure, such as high risk, high investment, complex organization and low income [21]. Additionally, it has another two special characteristics: geographic network and spatial externality [22]. On the one hand, transport infrastructure is a network infrastructure that constitutes the channel between nodes, regions or node-region. This promotes the spatial transfer of production factors and mobility of goods. On the other hand, the externality means that positive or negative effects on external subjects are generated when one economic entity produces or consumes. In terms of positive externalities, transport infrastructure as a public investment could directly promote economic growth and also indirectly increase the economy through spillover effects such as knowledge spillover effect and technology spillover effect. Meanwhile, environmental pollution and urban noise often happen 
because of the building of transport infrastructures, driving the generation of negative spillover effects. The existence of complex characteristics and significant roles drives the generation of multiple impacts of transportation infrastructures on the economy, society and environment.

\subsection{The Multiple Impact of Transportation Infrastructure}

The transportation infrastructure represents the motivator of economic growth and social welfare [23] through improving production performances and investment performances for the private sectors [24]. More specifically, the construction of transportation infrastructure could reduce the travel cost, attract foreign investment and expand trade of shared resources [25]. In terms of the social overhead capital, transport infrastructure plays a decisive role in industrialization and has obvious spillover effects on regional innovation, factor reallocation and manufacturing productivity [26], which promote the aggregation of industries, population and economy [16]; this is often called the economic distributional effect. However, some empirical studies have shown that the expansion of high-speed railway networks promotes the development of central cities but causes the economic growth rate of prefecture-level cities along the rail line to decline, which is referred to as the siphon effect [27]. Although different results were found based on various data sources or research objects, the empirical study is the most common and effective method to identify the positive or negative effects of transportation infrastructures.

Meanwhile, excessive infrastructure construction could put huge pressure on the natural and ecological environment when meeting the need for economic development and social improvement [28]. Transportation infrastructure provides the fundamental conditions for economic activities, while some spillover effects happen concomitantly [29], such as $\mathrm{CO}_{2}$ emission generated via domestic and global production networks [30], ecological destruction because of the biological habitat fragmentation [11] and the change of water flow and declining water quality [31,32]. Since the United States published the Environmental Impact Assessment (EIA) in 1969 [33], environmental problems have become a significant part of the law, and many topics have received wide attention. For the transport sector, apart from cost-benefit, design and investment analyses, environmental impacts such as $\mathrm{CO}_{2}$ emission and air quality are the main evaluation criteria [34]. In addition, some universal and systematic methods have been used to evaluate environmental performances, such as the multi-criteria model, meta-analysis [35], ecological footprint index [36], and value equilibrium analysis [37]. From the perspective of the environment, the effects of the transportation infrastructure are almost all negative, so minimizing the environmental impact has been the main research topic. Additionally, transport infrastructure assumes important social responsibility [38,39]. Although more jobs and optimized income distribution occurs after huge capital investments in infrastructure projects, health hazards, land expropriation and wildlife damage problems should not be neglected.

The multiple impacts of transportation infrastructures have received huge attention. However, the economic externality is still the most important and popular topic, which often ignores the environmental and social aspects [40]. Since the sustainable development topic has been a point of focus, the sustainable evaluation of transportation infrastructure has been increasingly valued. Based on the traditional cost-duration-quality decision model [41], plenty of indicators and methods have been extended to identify and assess transportation sustainability. For example, some multi-criteria models based on panel data have been extended, such as the multivariate co-integration approach [23], fuzzy logic evaluation [42] and the decoupling model [43]. In addition, optimizing the network structure and analyzing the spatial relationships of infrastructure operation are the key ways to promote the urban sustainability [44]. The complex characteristics and multiple impacts of transportation infrastructures have promoted studies on the identification and modelling of transportation sustainability. However, existing studies have mainly depended on experience to review the published articles. In addition, systematic and scientometric analysis could show complete and clear research status in this field. 


\section{Method}

In the field of transportation, many reviews have been published to identify the research status, while most reviews have mainly depended on researchers' backgrounds and experiences. To build an overview of existing studies with a relatively complete literature, the scientometrics method was used to find out the scientific regularity related to the effects of transportation research based on mathematical statistics and computing techniques [45]. In addition, scientometric analysis mainly depends on bibliographic data to identify the research trends and literature relationships [46]. The scientometric method was used in this study to build a visual information graph for further data mining using the software Citespace (http:/ / cluster.cis.drexel.edu/ cchen/citespace/). The visualization process of the bibliography is meaningful for discovering the potential information based on the graphical representation of data using shapes, colors and images [47]. This method reduces the difficulty in analyzing a large literature, and effectively finds the regularity and the hidden information in existing studies. In this section, the data overview and research path of the scientometric method are presented.

\subsection{Data Overview}

The Web of Science (WOS) database was used to collect published literature data related to the transportation infrastructure. Apart from WOS, Google Scholar's database is extensive, but its citation information is incomplete and inconsistent [48]. Therefore, it is difficult to use for scientometric analysis. In addition, WOS contains the most important and influential journals in the world $[49,50]$. The impact of transportation infrastructure includes many categories, such as human, economic and environmental. Therefore, in this section, a comprehensive data overview is presented to show the trend of existing studies. In addition, "transport infrastructure" and "transportation infrastructure" were used as keywords to collect the data, initially.

This paper analyzed all collected literature in the WOS core database from 2000 to 2017. The search code SS = (transport* infrastructure*) was used in the WOS core collection. Here, "*" denotes a fuzzy search and "SS" means an article subject search. A total of 2543 bibliographic records were collected in October, 2017, and there are 14 related records filtered by being highly cited in the field, as shown in Table 1. Highly cited papers are the top one percent in each of the 22 Essential Science Indicators (ESI) subject areas per year, which indicates scientific excellence. We can see that this literature is distributed over recent years, and almost all records are related to the environmental dimensions. It is notable that the highest cited article was published in 2012 and is about biofuel application in transportation vehicles. Additionally, Figure 1 shows the top 20 research fields related to transportation infrastructure, including engineering, transportation, business economics, environmental sciences, computer science, geography, public administration, urban studies, and so on. This means the studies related to transportation infrastructure range from the technological level to the management level, providing more challenges and opportunities to interdisciplinary research.

The data overview above shows the overall research trends and fields. According to the research scope and objects, some keywords are chosen to filter the results that are more related to the spillover effects of the transportation infrastructure network. Then the words $\left(\mathrm{SS}^{\prime}=\right.$ effect $^{*}$ or affect* ${ }^{*}$ or influence* or impact*) were selected to refine the results, and a total of 1568 bibliographic records were searched. This step refined the records referring to the impact of transportation infrastructures or other effects on transportation infrastructure. Finally, the main keywords $\left(\mathrm{SS}^{\prime \prime}=\right.$ railway* or rail* or road* or highway* or expressway* or freeway*) were used to further refine these results in accordance with the specific research objects of this paper, and got 764 records. Figure 2 shows the distribution of 1568 bibliographic records related to the two-way influence of transportation infrastructure and the records related to the influence of railway or road. In addition, the final 531 papers were used for further review analysis. Multi-step data filtering benefits a narrow data range, promoting study depth and guaranteeing the data integrity. It is clear that the distribution trend of is similar between the original data and the filtered data, which means the impact of railway and road could follow the path of the development of 
transportation infrastructure. In addition, research about the impact of railways and roads accounts for around $20-40 \%$ of research on transportation infrastructure during the timespan. In other words, the analysis of railways and roads partially represents the transportation infrastructure.

Table 1. Top highly cited research categories.

\begin{tabular}{|c|c|c|c|c|c|}
\hline \multirow{2}{*}{ Title } & \multirow{2}{*}{ Cited } & \multirow{2}{*}{ Year } & \multicolumn{3}{|c|}{ Sustainable Dimensions } \\
\hline & & & Economy & Environment & Society \\
\hline Microbial engineering for the production of advanced biofuels & 409 & 2012 & $\checkmark$ & $\checkmark$ & \\
\hline $\begin{array}{l}\text { Grasping at the routes of biological invasions: a framework } \\
\text { for integrating pathways into policy }\end{array}$ & 361 & 2008 & & $\checkmark$ & \\
\hline $\begin{array}{l}\text { Catalytic routes for the conversion of biomass into liquid } \\
\text { hydrocarbon transportation fuels }\end{array}$ & 336 & 2011 & $\checkmark$ & $\checkmark$ & \\
\hline Liquid-phase chemical hydrogen storage materials & 294 & 2012 & $\checkmark$ & $\checkmark$ & \\
\hline $\begin{array}{l}\text { Plug-in Vehicles and Renewable Energy Sources for Cost and } \\
\text { Emission Reductions }\end{array}$ & 287 & 2011 & & $\checkmark$ & \\
\hline Adults' Sedentary Behavior Determinants and Interventions & 269 & 2011 & & & $\checkmark$ \\
\hline $\begin{array}{l}\text { From roadkill to road ecology: A review of the ecological } \\
\text { effects of roads }\end{array}$ & 259 & 2007 & & $\checkmark$ & \\
\hline $\begin{array}{l}\text { Urban green space, public health, and environmental justice: } \\
\text { The challenge of making cities 'just green enough' }\end{array}$ & 203 & 2014 & & $\checkmark$ & $\checkmark$ \\
\hline $\begin{array}{l}\text { Urban sprawl in the Mediterranean? Patterns of growth and } \\
\text { change in the Barcelona Metropolitan Region 1993-2000 }\end{array}$ & 170 & 2008 & & & $\checkmark$ \\
\hline $\begin{array}{l}\text { Robust alternative technology choices are required in the } \\
\text { paradigm shift from the current crude oil-reliant transport } \\
\text { fuel platform to a sustainable, more flexible transport } \\
\text { infrastructure. }\end{array}$ & 162 & 2011 & $\checkmark$ & $\checkmark$ & $\checkmark$ \\
\hline $\begin{array}{l}\text { Impacts of urbanization on urban structures and energy } \\
\text { demand: What can we learn for urban energy planning and } \\
\text { urbanization management? }\end{array}$ & 101 & 2011 & & $\checkmark$ & $\checkmark$ \\
\hline $\begin{array}{l}\text { Route Infrastructure and the Risk of Injuries to Bicyclists: } \\
\text { A Case-Crossover Study }\end{array}$ & 66 & 2012 & & & $\checkmark$ \\
\hline $\begin{array}{l}\text { Changes in mode of travel to work: a natural experimental } \\
\text { study of new transport infrastructure }\end{array}$ & 17 & 2015 & & $\checkmark$ & $\checkmark$ \\
\hline $\begin{array}{l}\text { Impact of New Transport Infrastructure on Walking, Cycling, } \\
\text { and Physical Activity }\end{array}$ & 12 & 2016 & & $\checkmark$ & $\checkmark$ \\
\hline
\end{tabular}

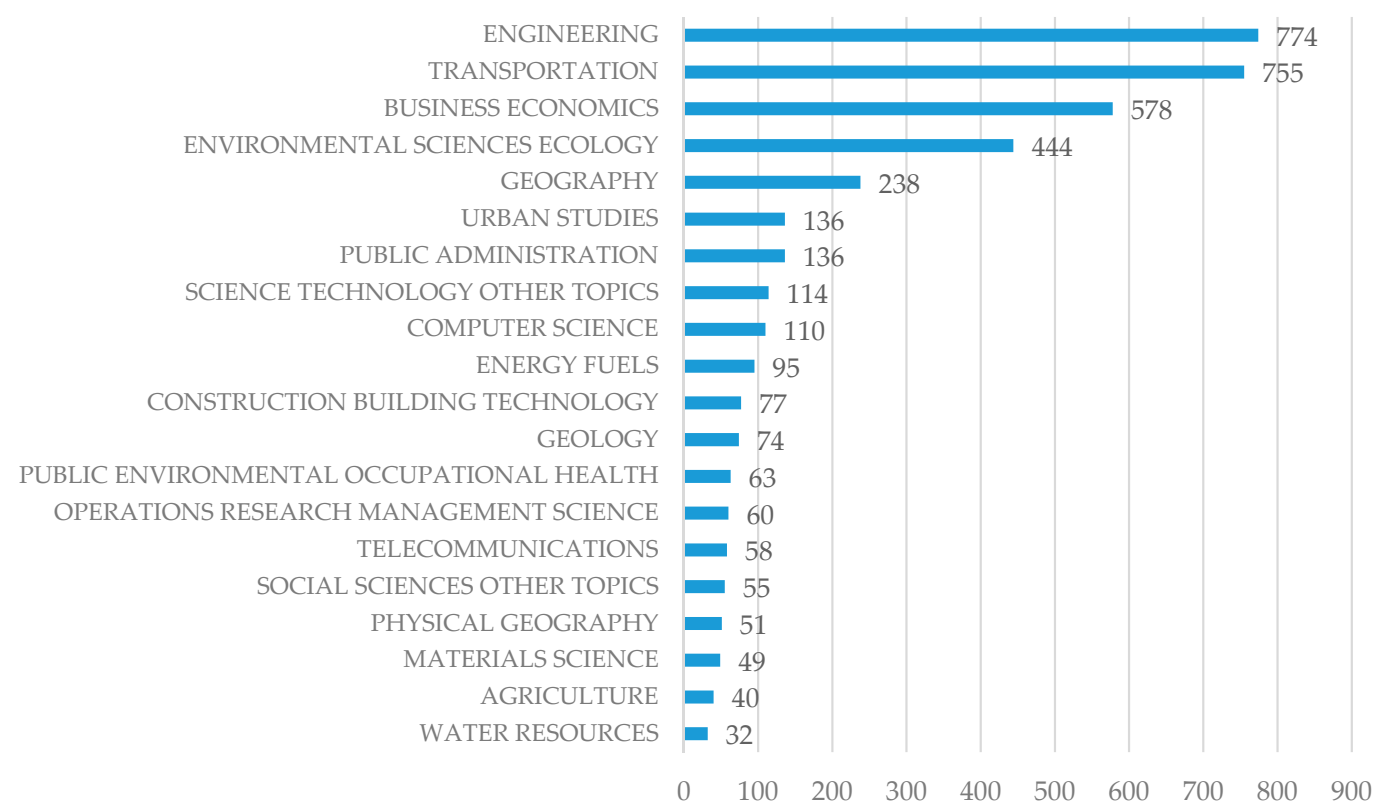

Figure 1. The top 20 research fields of the transportation infrastructure. 


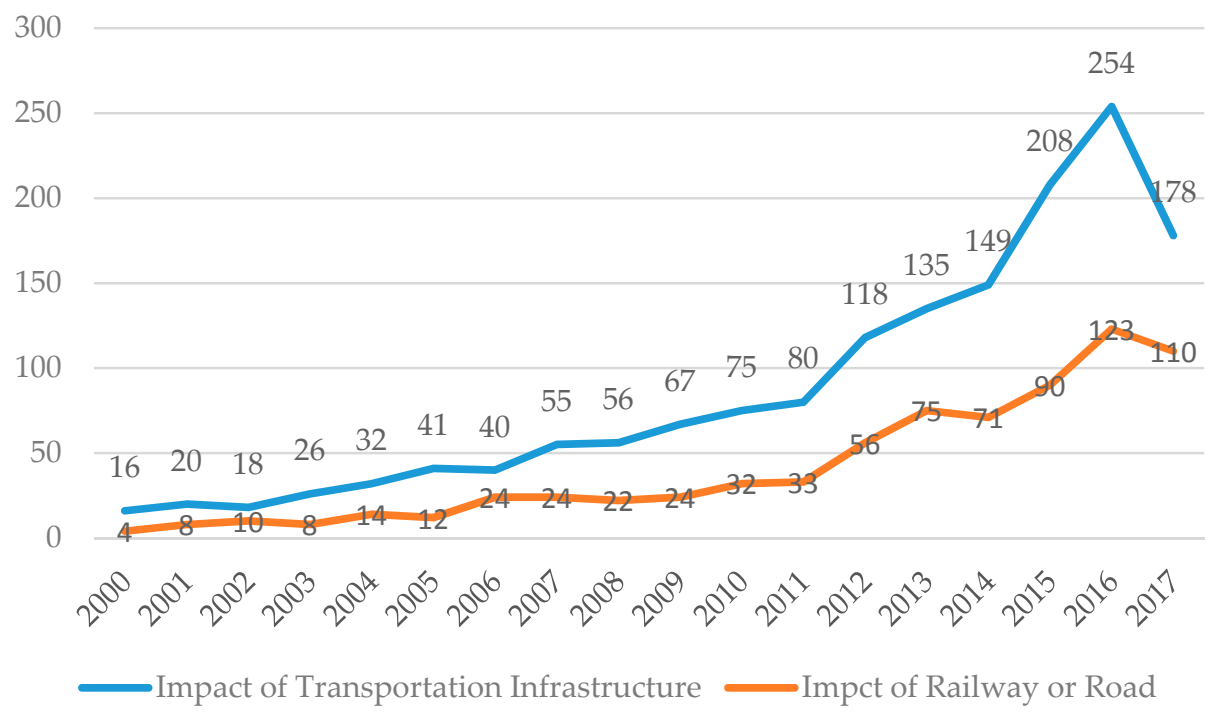

Figure 2. The number of articles on impact of transportation infrastructure.

\subsection{Scientometric Method}

Scientometric analysis is a systematic method to identify and analyze the published literature, and it has become increasingly frequently used to obtain a deeper understanding of a research area [51]. In addition, this analysis has been recognized as an efficient method to identify the hidden information in published bibliographies [52]. In the field of transportation, scientometric analysis has been used as a quantitative approach to identify research phenomena and trends $[14,15]$, but these previous studies did not systematically analyze the research network or recognize the hidden research trends and relations. The software CiteSpace can visualize the emerging trends, transient patterns, substantial theoretical and methodological contributions in scientific literature from the perspective of a social network $[53,54]$. The accessible graphs based on network analysis and clustering algorithms are able to show the knowledge more logically and systematically [55]. Therefore, CiteSpace was used to identify and analyze the main effects of transportation infrastructure on sustainable development based on the literature. In this study, some scientometric techniques were used, such as fundamental information analysis (author, institution and country) and network analysis (subject, keywords and co-citation). According to these analysis results, the research challenges and trends were further systematically analyzed.

In detail, the research procedure of this study includes three main parts, according to the collected bibliographic data, as shown in Figure 3. Firstly, 2543 records were collected to perform the data overview, including the highly cited analysis and the top 20 research fields. After the filtering, 2056 records were analyzed by CiteSpace software to show representative people, institutions, countries and relationships among them. Then the dual-map overlay and keyword network of the literature were analyzed to show representative research subjects and issues. Additionally, references in the collected literature were analyzed to build the co-citation network, which generates the clustering information to expand the data source. Finally, according to the clustered information, the research status and trend were summarized systematically to generate the hierarchy of key concepts. All of these steps reviewed the bibliographic information from different dimensions to find the respective research issues. 


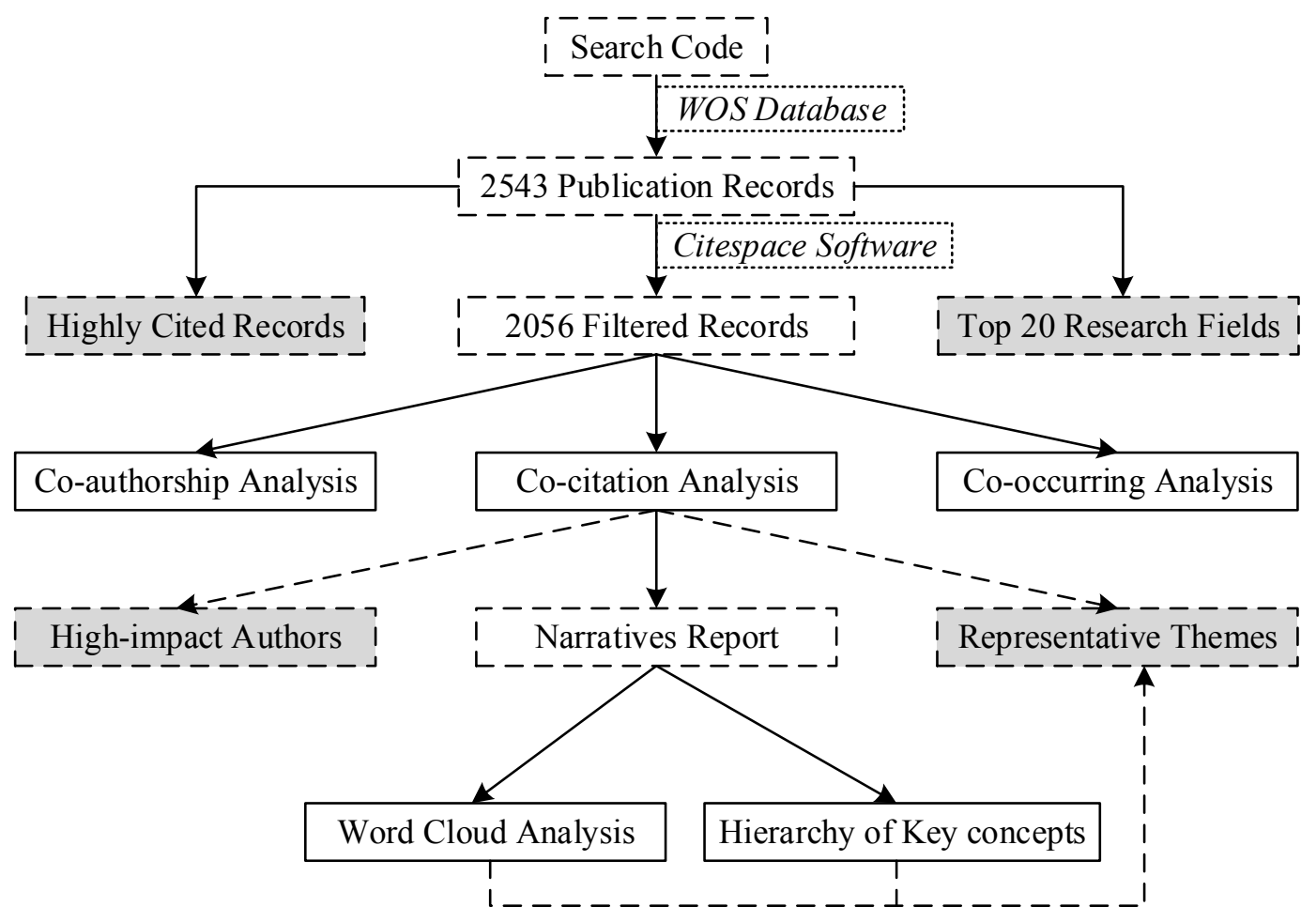

Figure 3. Research procedure of this study.

\section{Results and Discussion}

\subsection{Co-Authorship Analysis}

According to the author collaboration analysis, the domain authors have a relatively large number of links to other authors in the network, which means the domain authors have higher academic relevance [56]. In this study, 2056 valid bibliographic records were collected from 2000 to 2017. The co-authorship network is shown in Figure 4, where each node represents an author and links between authors denote collaboration established through co-authorship of articles. In this network, excessive links were removed by Pathfinder using network pruning [57], and eventually 189 nodes and 173 links were identified. In addition, the node size represents the frequency of published references and the node color accounts for different collaboration modularity.

According to the cluster information from 2000 to 2017, the network density is 0.0097 and the cluster modularity $\mathrm{Q}$ is 0.8626 , which means the network of co-authors is fragmented. Only a few closed circuits exist in the network, such as the Mulley C group, Flyvbjerg B group and Ogilvie D group. As shown in the left-bottom graph of Figure 4, many authors collaborated with one or two productive authors. For example, Flyvbjerg Band Van Wee B were both productive and central authors in the community. All centralities of these groups are small, which indicates that in the timespan 2000-2010, important collaboration groups were not formed by author centrality. In order to determine the timeliness of the study, the research period was limited to 2010-2017. In addition, the right-bottom graph of Figure 4 shows the author collaboration network during this period. In this network, 1899 valid records are included and there are 185 nodes and 172 links. The network density is 0.0101 , which is similar to the left graph. The network modularity and network structure only change slightly. It is notable that the author clusters change slightly, which means these central authors play significant roles in this field. Overall, from the perspective of timespan, author collaboration groups remained stable and relatively separate from the increased cumulative number of works in the published literature. 


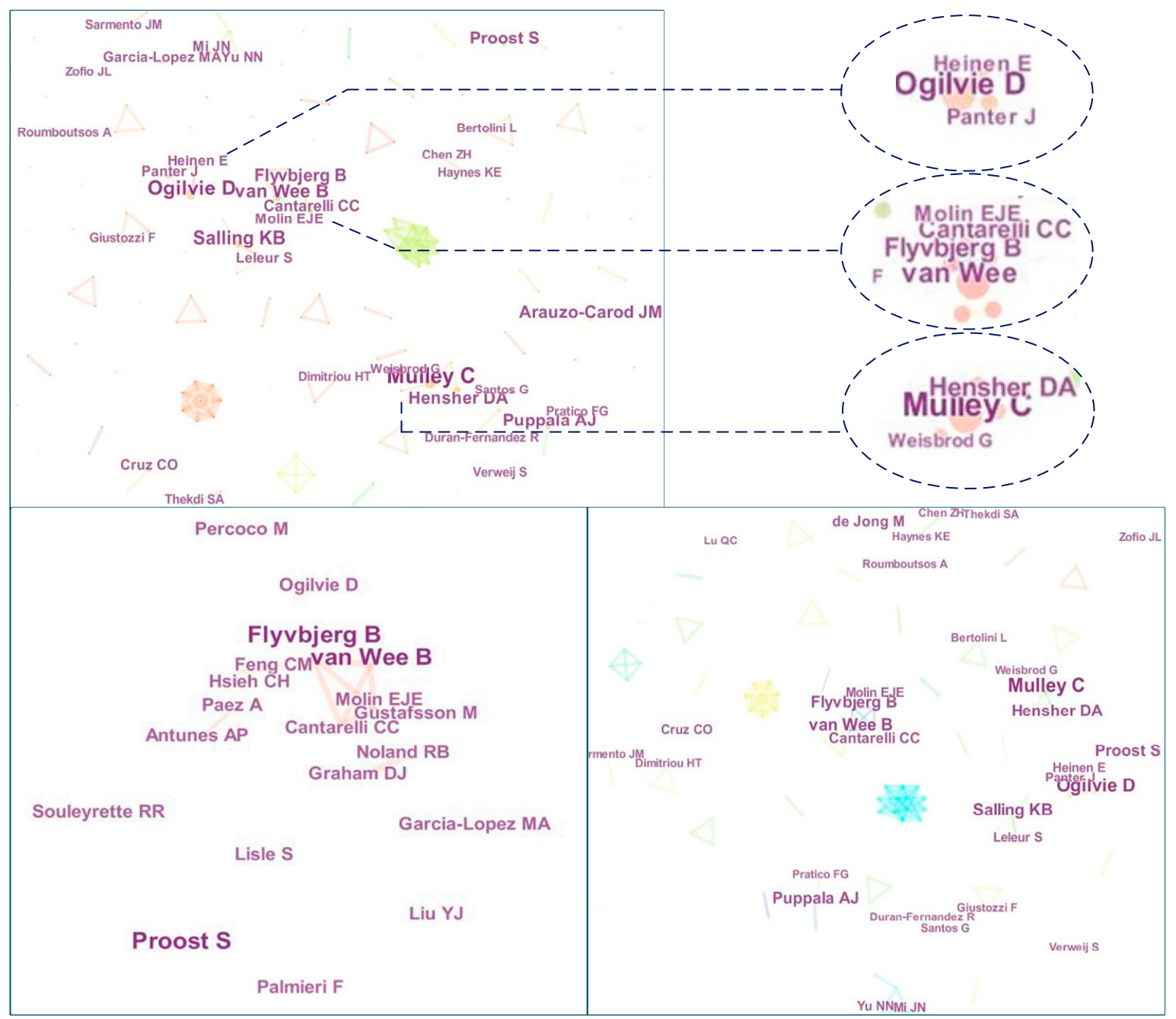

Figure 4. Comparison of author collaboration networks.

Apart from the collaboration analysis, author productivity is an important criterion to show the roles of authors or teams. Based on the 2056 collected bibliographic records, the top 10 most productive authors were identified in Table 2. This shows that the main research fields of the hot authors include transportation, business economics and environmental management. More importantly, the collaboration links among most productive authors were more frequent and the productive authors generally led to modularity. For example, the productive author Flyvbjerg Bent cooperated with another productive author Van Wee Bert and the productive authors Ogilvie David, Flyvbjerg Bent and Mulley Corinne generated co-author modularity, as shown in Figure 4, which means that the productive authors were often cited and focused upon. 
Table 2. Top ten most productive authors.

\begin{tabular}{|c|c|c|c|}
\hline Author & Institution & Count & Research Field \\
\hline Flyvbjerg Bent & University of Oxford & 15 & $\begin{array}{c}\text { Transportation, Business Economics, Public } \\
\text { Administration, Urban Studies, Environment } \\
\text { Sciences Ecology, Geography }\end{array}$ \\
\hline Mulley Corinne & University of Sydney & 13 & $\begin{array}{l}\text { Transportation, Business Economics, Geography, } \\
\text { Engineering, Environmental Sciences Ecology }\end{array}$ \\
\hline De Jong Martin & $\begin{array}{l}\text { Delft University of } \\
\text { Technology }\end{array}$ & 12 & $\begin{array}{l}\text { Transportation, Business Economics, Government } \\
\text { Law, Public Administration, Geography }\end{array}$ \\
\hline Ogilvie David & $\begin{array}{l}\text { University of } \\
\text { Cambridge }\end{array}$ & 12 & $\begin{array}{l}\text { Public Environmental Occupational Health, } \\
\text { Nutrition Dietetics, Physiology }\end{array}$ \\
\hline Proost Stef & $\begin{array}{l}\text { Katholieke Universiteit } \\
\text { Leuven }\end{array}$ & 12 & $\begin{array}{c}\text { Transportation, Business Economics, Engineering, } \\
\text { Operations Research Management Science, } \\
\text { Environmental Sciences Ecology, Geography }\end{array}$ \\
\hline Salling Kim Bang & $\begin{array}{l}\text { Technical University of } \\
\text { Denmark }\end{array}$ & 11 & Transportation, Business Economics \\
\hline Van Wee Bert & $\begin{array}{l}\text { Delft University of } \\
\text { Technology }\end{array}$ & 11 & Transportation, Business Economics \\
\hline $\begin{array}{l}\text { Durango-Cohen } \\
\text { Pablo }\end{array}$ & $\begin{array}{l}\text { Northwestern } \\
\text { University }\end{array}$ & 10 & $\begin{array}{l}\text { Engineering, Transportation, Business Economics, } \\
\text { Operations Research Management Science }\end{array}$ \\
\hline Hensher David A & $\begin{array}{l}\text { University of New } \\
\text { South Wales }\end{array}$ & 10 & $\begin{array}{l}\text { Transportation, Business Economics, } \\
\text { Engineering, Geography }\end{array}$ \\
\hline $\begin{array}{l}\text { Manuel Vassallo } \\
\text { Jose }\end{array}$ & $\begin{array}{c}\text { Universidad } \\
\text { Politécnica de Madrid }\end{array}$ & 10 & Transportation, Engineering, Business Economics \\
\hline
\end{tabular}

\subsection{Co-Author's Institution and Country Analysis}

As shown in Figure 5, the institution network includes 280 nodes and 236 links from 2000 to 2017. The node size represents the amount of published literature from one institution. According to the collected information, the studies related to transportation infrastructure were rich at institutions such as Delft University of Technology (50 records), University of Sydney (33 records), Universidad Politécnica de Madrid (29 records), University College London (28 records), University of Oxford (28 records) and Chinese Academy of Sciences ( 25 records). This indicates that transportation infrastructure research was active and advanced. In addition, institution nodes with high betweenness centrality are shown in Figure 5. The size of the colored circle represents the amount of published literature in one institution, and different colors show the number in different years. Institutions with high centrality play important roles in the institution network, such as Delft University of Technology (centrality $=0.24$ ), University of Illinois (centrality $=0.17$ ), Georgia Institute of Technology (centrality $=0.14$ ), Shanghai Jiao Tong University (centrality $=0.12$ ) and University of Florida (centrality $=0.10$ ), and they drove the research collaborations among different institutions. Apart from the Delft University of Technology, the top productive institutions did not have higher relative centrality. This means that institutions that published more articles did not play an equally important role in the collaboration network. The institutions with higher centrality would have greater potential. 


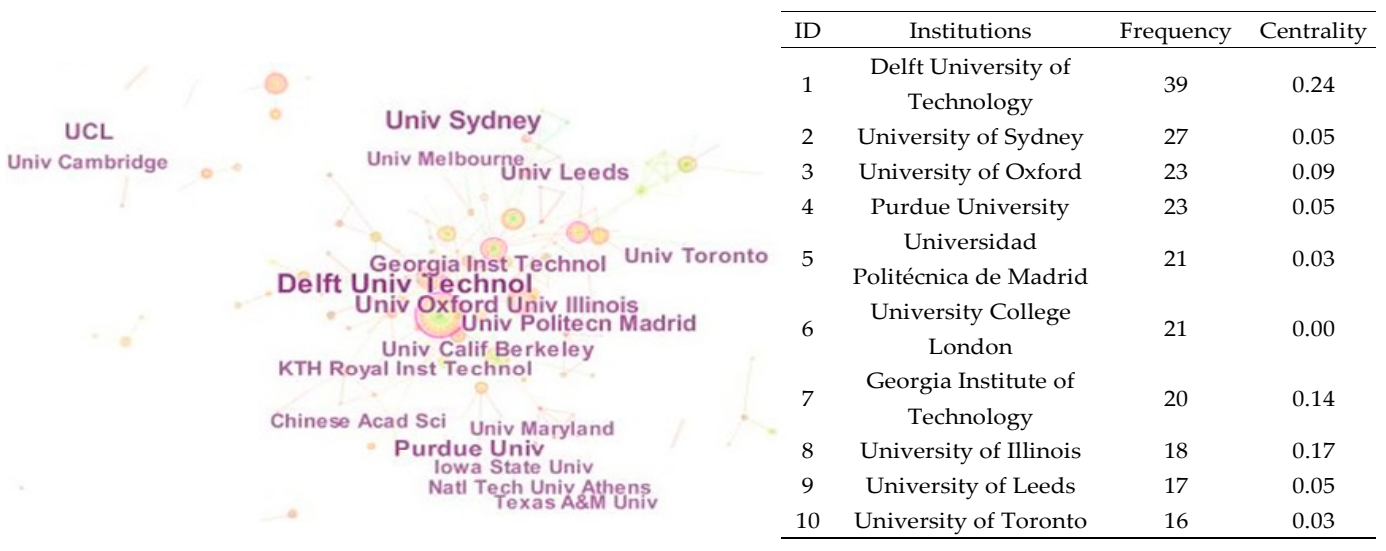

Figure 5. Institution collaboration network.

Furthermore, Figure 6 shows the country collaboration network in 2000-2010 and 2010-2017; clusters are displayed in different colored circles and they are arranged vertically in the order of their size. In addition, the colored lines represent co-citation links among different countries. During 2000 to 2010, as shown in the left graph, the top 5 countries with the highest centrality include USA (centrality $=0.65)$, England (centrality $=0.4)$, Sweden (centrality $=0.36)$, Italy (centrality $=0.21$ ) and Japan (centrality $=0.14$ ), which means that they occupied key positions in the collaboration network. During 2010 to 2017, as shown in the right graph, the top 5 countries with the highest centrality include USA (centrality $=0.53$ ), England (centrality $=0.31$ ), Germany (centrality $=0.17$ ), Australia (centrality $=0.15$ ) and the People's Republic of China (centrality $=0.1$ ). We can see the centralities of USA and England experienced a decrease and the roles of Germany, Australia and the People's Republic of China became increasingly significant. Additionally, apart from the top central countries, Spain, Netherlands and Canada had higher published frequencies, which indicates their higher relative potentials. According to the clustering results, we can see the change of research interests. The labels of clusters were generated by log-likelihood ratio method in the software. It is notable that during 2000-2010, an overview of popular topics included infrastructure surveillance, local development and evidence; during 2010-2017 those consisted of transportation decision, regional development and infrastructure surveillance. In addition, the clustering members experienced an increase and transfer.

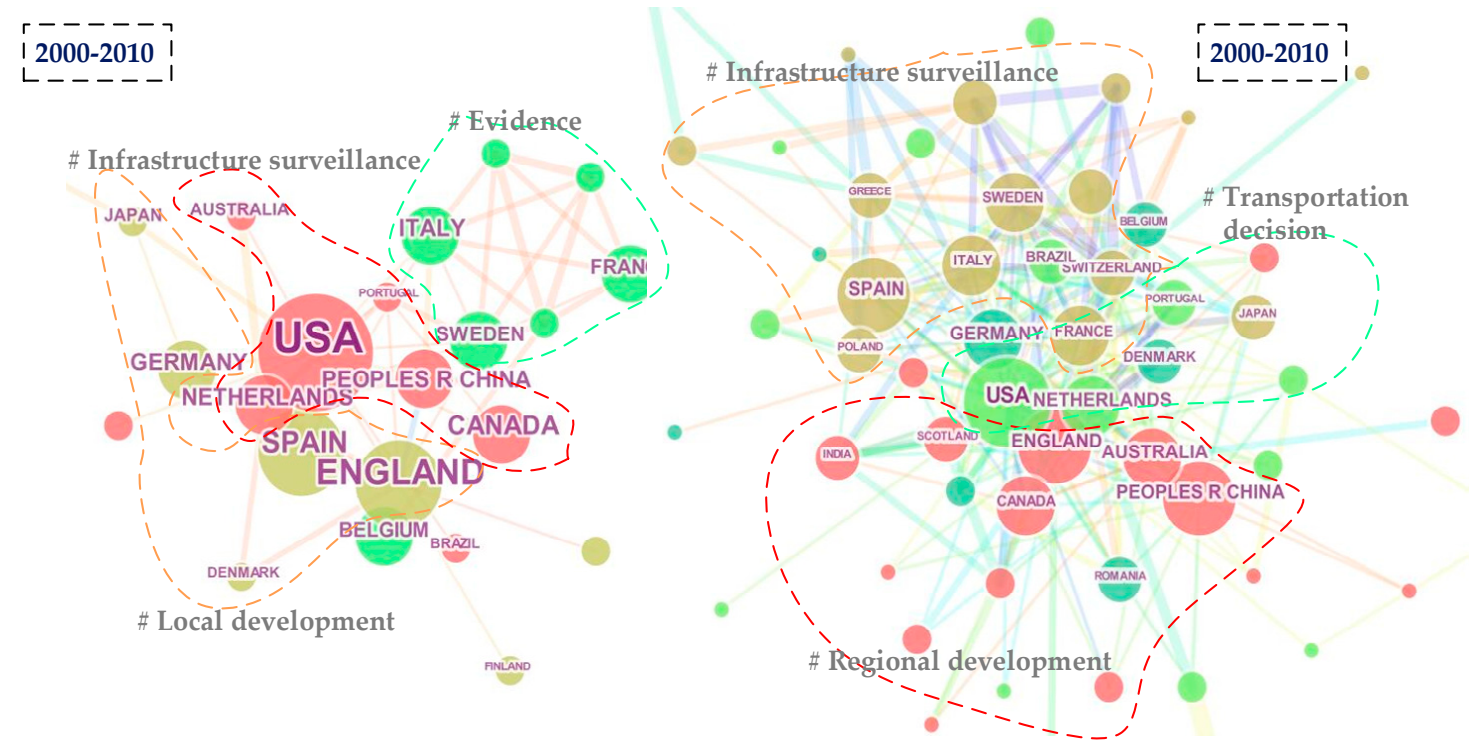

Figure 6. Comparison of country collaboration network. 


\subsection{Co-Occurring ANALYSIS}

\subsubsection{Discipline Analysis}

Every citation and cited work was assigned to a specific research discipline according to the journals in a global map of science generated from over 10,000 journals indexed in the WOS [58]. Therefore, this study built an overlay map to show the dual-map of the science sketch database that perfectly described the interdisciplinary research. Figure 7 shows the main disciplines of collected citing articles and cited articles. The left part of the graph shows the distributed disciplines of citing articles and the right part describes that of cited articles. In addition, the color curves represent the fluctuant relations. It is clear that the journals of citing articles related to transportation infrastructure are mainly distributed in disciplines such as mathematics, systems, economics and physics. Cited articles' journals are mainly distributed in the areas of ecology, computer, social education and economics. The distribution of cited articles indicates the application fields and research foundations. More importantly, transportation infrastructure papers are published in almost all major disciplines, which means transportation infrastructure studies play important roles in multidisciplinary research. Additionally, the dual-map overlay shows the information about the field studies more macro compared with article clustering analysis. Thus, Figure 8 shows the interdisciplinary co-occurring network of the literature based on the WOS discipline categories. We can see that the top frequent disciplines include Engineering, Transportation and Business \& Economics. The links among different nodes mean the existence of collaboration among different disciplines. Interdisciplinary research is quite obvious in the field of transportation infrastructure.

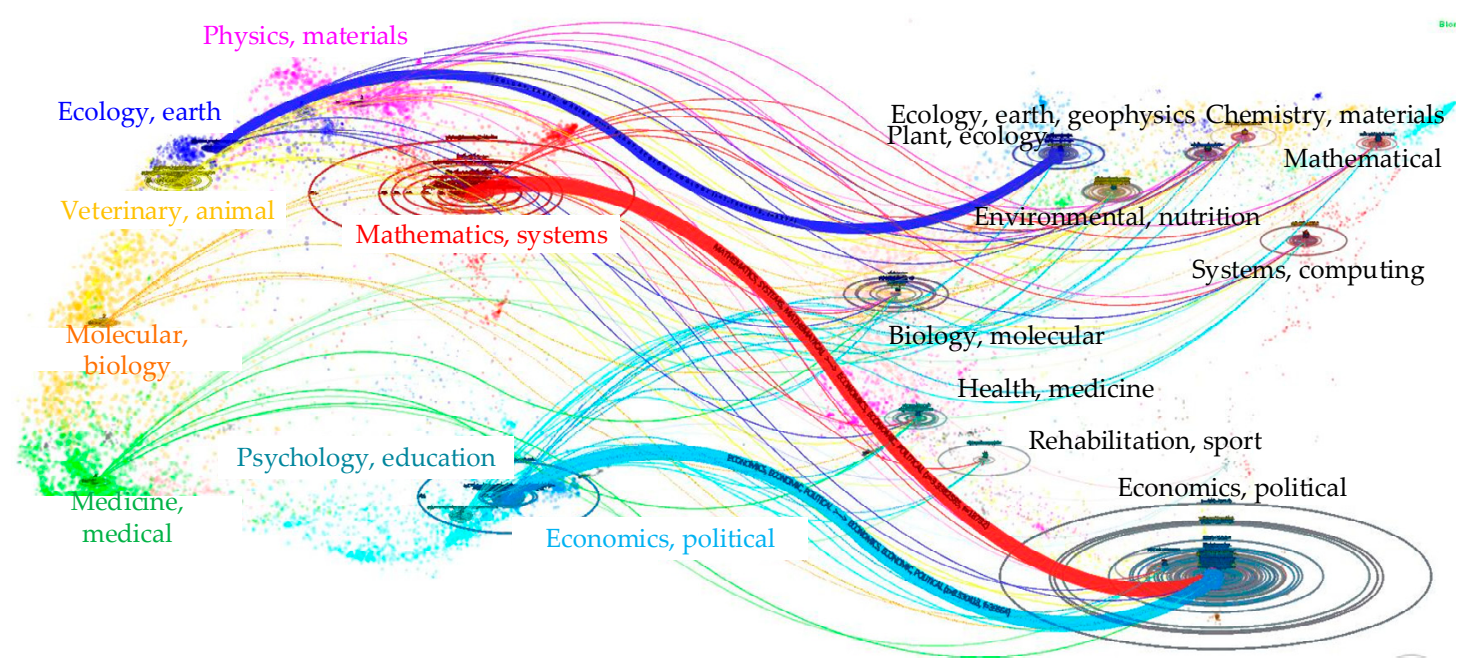

Figure 7. A dual-map overlay of the literature's journals. 


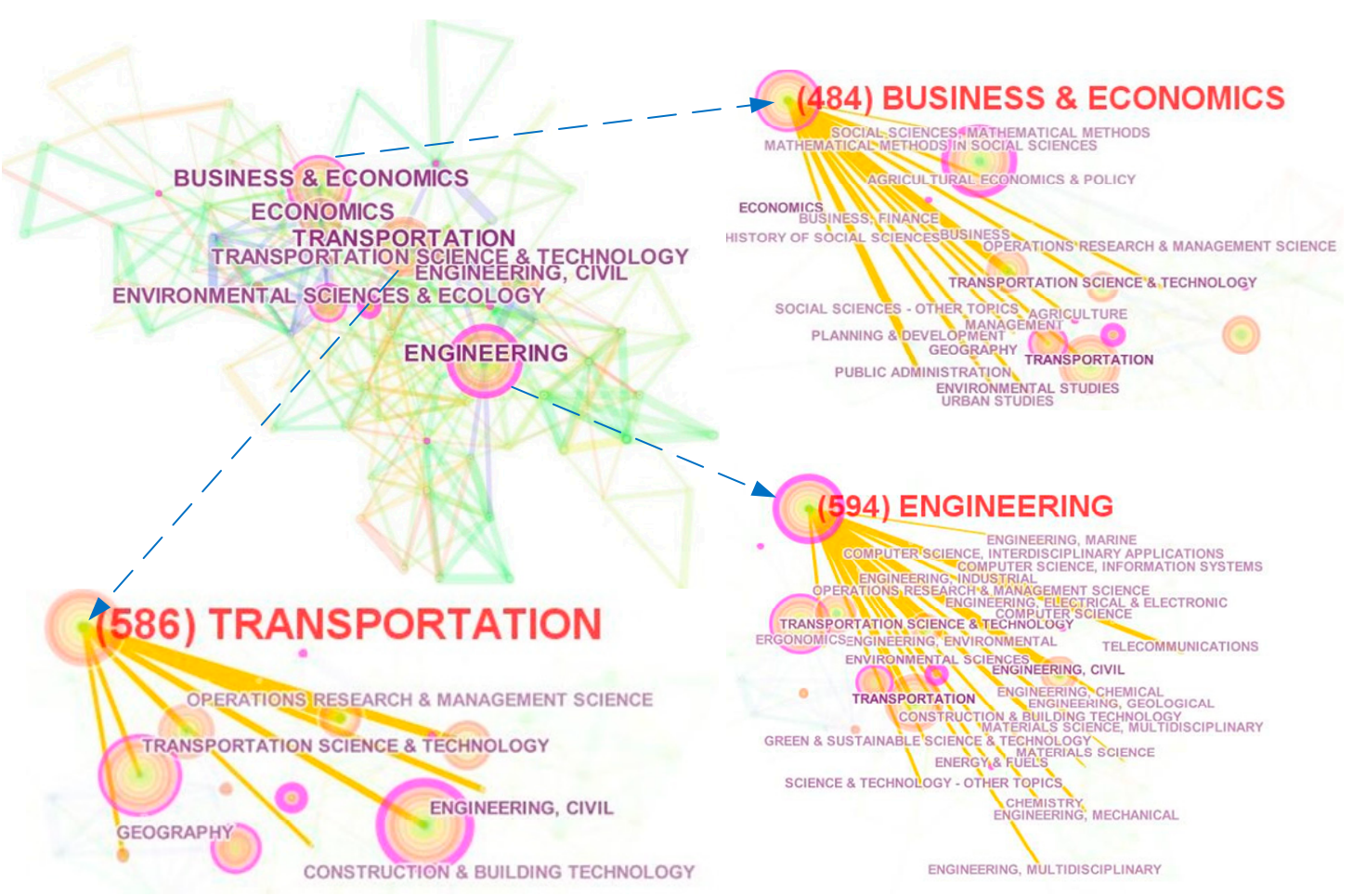

Figure 8. Inter-disciplinary co-occurring network of the literature.

\subsubsection{Co-Occurring Keyword Analysis}

Keywords catch the core content of a paper, and in this section, the collected keywords show the situation and development of research using the software CiteSpace. According to the 2056 valid records collected, the keyword co-occurring network includes 225 nodes and 1092 links shown in Figure 9. The node size represents the frequency of a keyword in all records and links among nodes indicate different keywords occurring in the same record. The t-SNE view was used to lay out the keyword map. The t-SNE technique is a perfect visual method for this map, and gave a complete and clear description. Among the top 50 hot keywords, the most frequent keywords include model (frequency $=176$ ), impact (frequency $=120$ ), system (frequency $=109$ ), growth (frequency $=94$ ), investment (frequency $=86$ ), network (frequency $=85$ ), accessibility (frequency $=80$ ), city (frequency $=74$ ) and policy (frequency $=72$ ), in addition to transportation infrastructure (frequency $=225$ ). More importantly, China (frequency $=86$ ) and the United States (frequency $=52$ ) are two representative country keywords, which means that in these two countries, studies related to transportation infrastructure attracted more attention. In addition, some keywords with high frequency had a relatively high centrality, such as city (centrality $=0.15$ ), network (centrality $=0.14$ ), investment (centrality $=0.12$ ) and impact (centrality $=0.09$ ). To indicate the change of hot topics, we divided the timespan into 2010-2010 and 2010-2017, as shown in Figure 9. The top three keywords are model, infrastructure and impact. The related keywords experienced a significant increase; in particular, keyword impact-related topics included climate, urban studies, land use, resilience and accessibility, which indicated this role. However, this network only shows information based on the collected records, and its difference from the co-citation network is the limitation of this relatively incomplete data. Therefore, the co-citation analysis further solves the data incompleteness in the next section. 


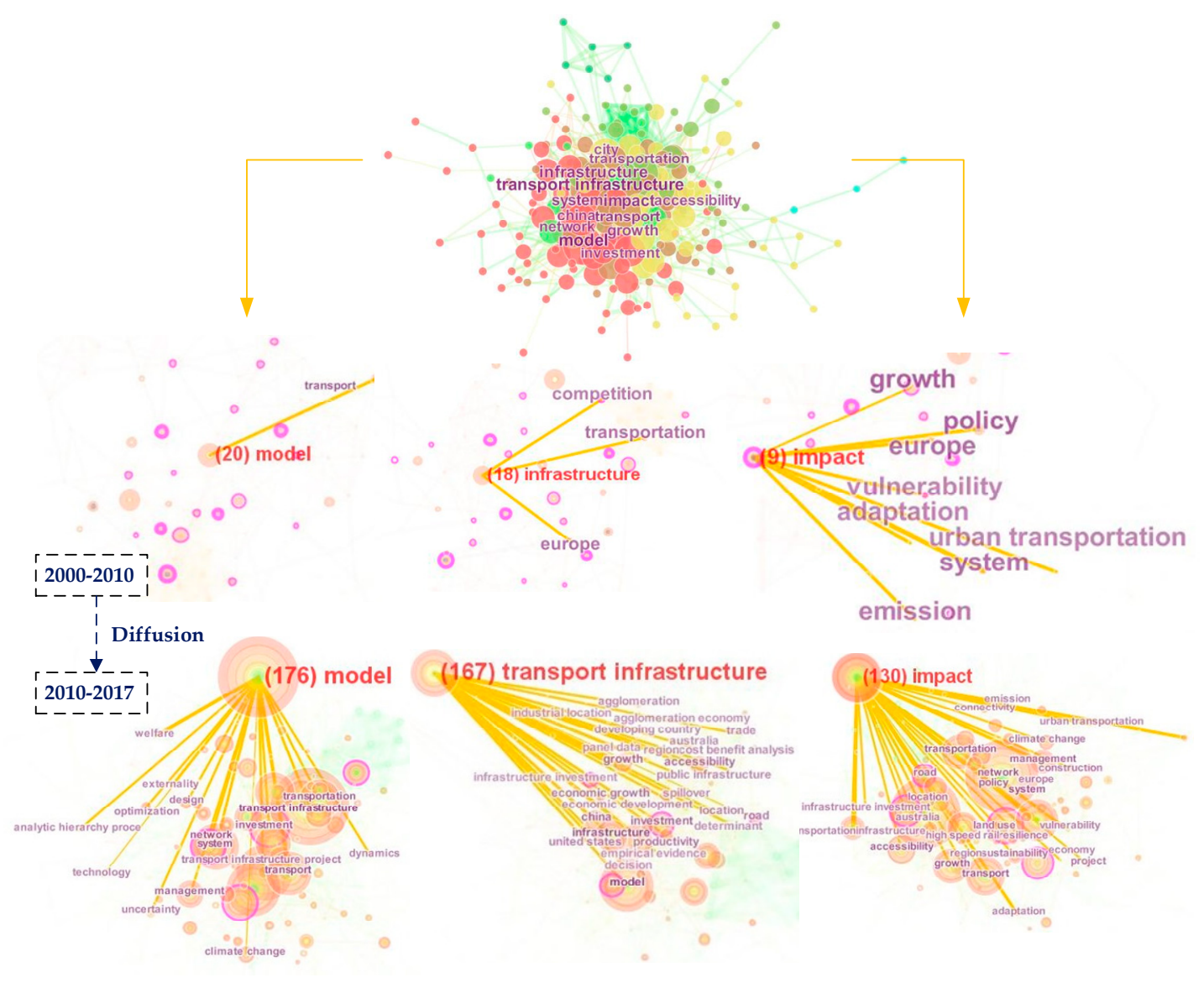

Figure 9. Keyword co-occurring network diffusion.

\subsection{Co-Citation Analysis}

Co-citation analysis has been defined as the frequency with which two articles are cited together in another article [59]. In this section, co-citation analysis identifies the underlying intellectual structures of the knowledge in the field of transportation infrastructure according to references. The co-citation network was generated based on 2047 valid records between 2000 and 2017, and the top 50 most cited publications in each year were used to construct a network of references cited in that year. As shown in Figure 10, the synthesized network contains 879 references and 174 co-citation clusters after the clustering process. This network has a modularity of 0.8934 , which is considered to be very high, suggesting that the specialties in science mapping are clearly defined in terms of co-citation clusters. The mean silhouette is 0.3855 , which is relatively low, mainly because of the numerous small clusters. The major clusters that we focus on in this paper were sufficiently high. The areas in different colors indicate the time at which co-citation links in those areas appeared for the first time. Areas in green were generated earlier than areas in yellow. Each cluster can be labeled by title terms, keywords, and abstract terms of articles citing the cluster. We can see that studies related to new application, cost overruns and case study appeared earlier, and urban transportation and public-private partnerships appeared more recently. In addition, cluster areas of new transport infrastructure, cost overruns and evidence study are relatively bigger, which means that these studies received more attention. According to the LLR, labels of the largest 62 clusters were summarized as shown in Appendix A and the most active citer can be checked in Appendix B. 


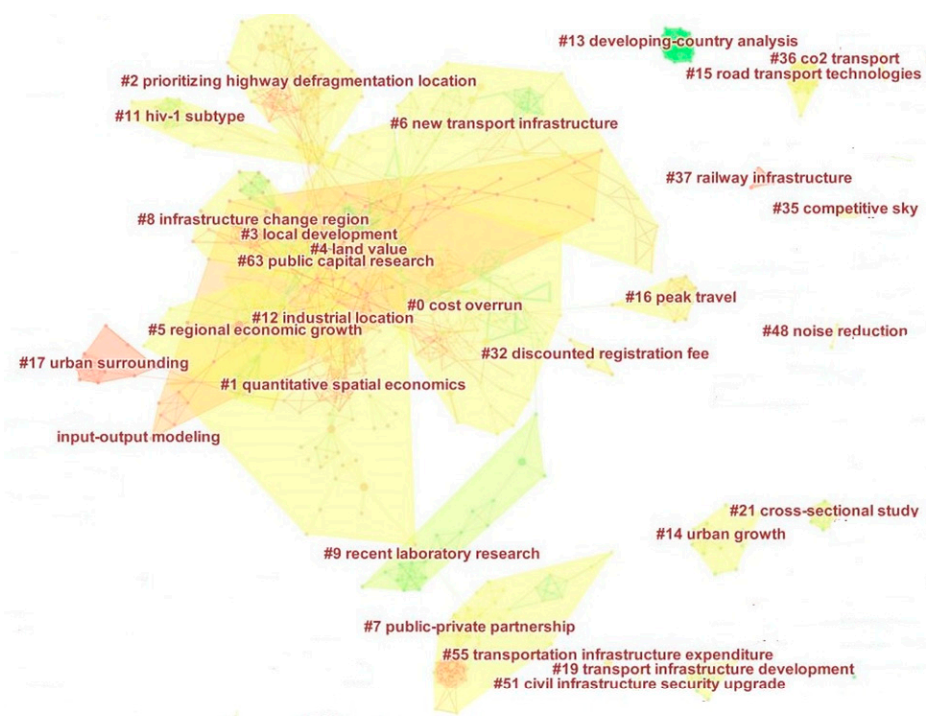

Figure 10. A landscape view of the co-citation network.

In addition, the timeline visualization in CiteSpace depicted clusters along horizontal timelines. As shown in Figure 11, each cluster was displayed from left to right and clusters were arranged vertically in descending order of their size. The colored curves represent co-citation links added in the year of the corresponding color. Large-sized nodes or nodes with red tree rings received particular attention because they were either highly cited or had citation bursts, or both. We can see that the three most-cited references in a particular year are displayed. The labels of these references were placed in the lowest position. The cluster labels were generated based on terms identified by Latent Semantic Indexing (LSI) [60]. Figure 11 shows the top 2 largest clusters, listed as cluster\#0 and cluster\#1. The periods in which the clusters were sustained were different, which means that the difference of topic activity. For example, topic \#0 (cost overrun) was active during the period from 2008 to 2017 and most of the top active topics were active about 20 years. Furthermore, the top ten largest clusters include cost overrun, quantitative spatial economics, prioritizing highway defragmentation location, local development, land value, regional economic growth, new transportation infrastructure, public-private partnerships, infrastructure change region, recent laboratory research and microbial engineering. All of these clusters have relative network sub-structures and research status, and trends hide in these references. For example, for the cluster around spatial economics, 2011 to 2012 was the most active timespan for citers.

The analysis above shows the research base and fronts that mine the potential research challenges and trends. In addition, main research topics were further analyzed according to the selected and filtered data above. Table 3 shows the temporal properties of major clusters. We can see that most of the representative references are related to the spillover effect of the transportation infrastructure. For example, Cluster \#0 (cost overrun) is the largest cluster, containing 94 references from 2011 to 2017. The mean year of all references is 2008 and the year of the most representative cited articles in this cluster is 2008, too. The timeline visualization reveals the top three cited references from the period of 2000 to 2017. As shown in Figure 11, the three most representative cited references (Priemus Hugo, Banister David and Khadaroo Jameel) occur in 2008. We can see that the period 2008 to 2016 was full of high-impact contributions-large colored citation circles and red citation bursts. We chose the top three cited circles and nine references to analyze the main research topics. Similarly, in the other five clusters, the top three circles and nine representative references were chosen to further analyze the hot research status and research trends. Appendix $C$ shows the high-impact members of the other clusters. These authors may be not the most highly cited authors, but they play important roles in the corresponding fields. 


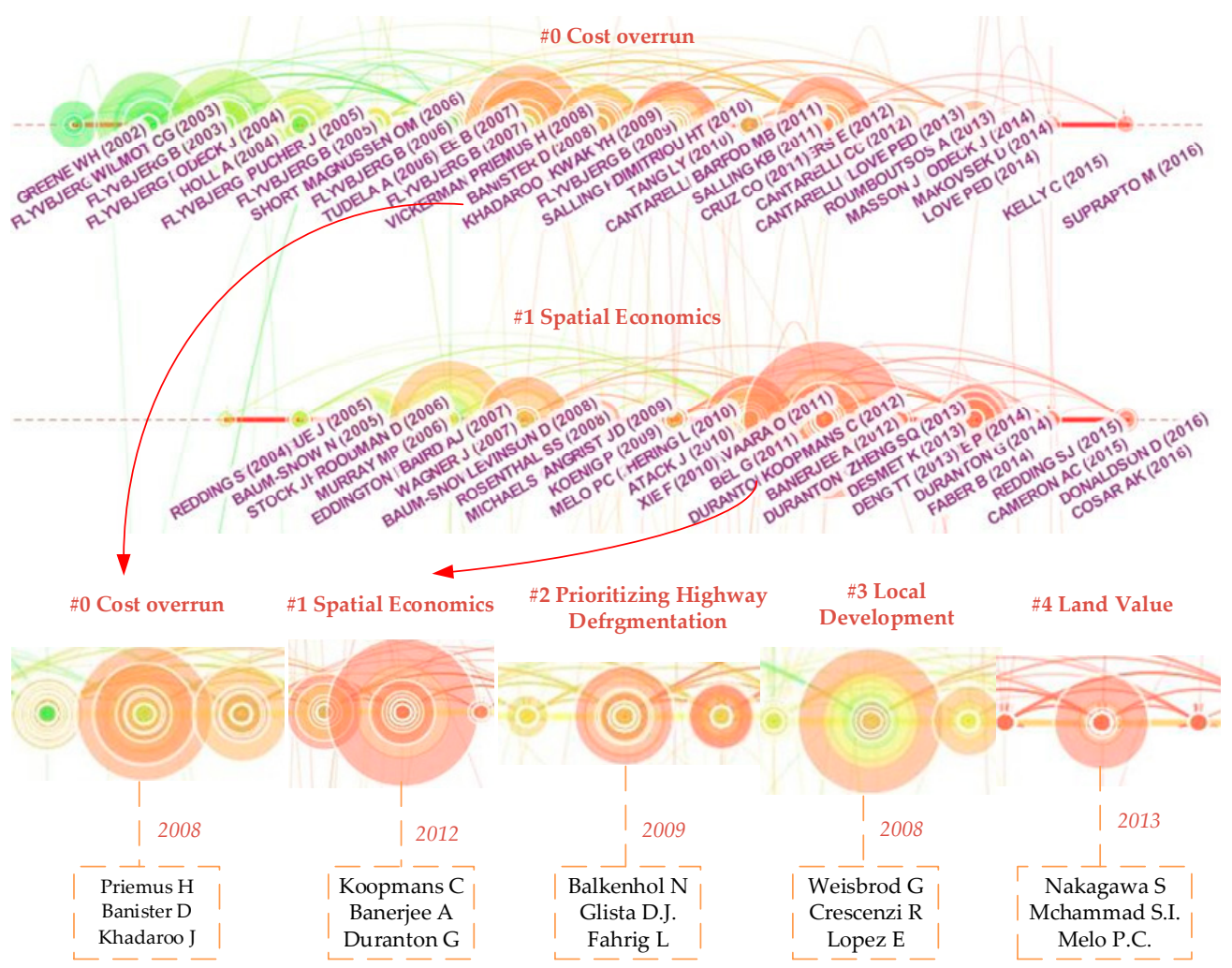

Figure 11. A timeline visualization of the largest clusters.

Table 3. Temporal properties of the major 6 clusters.

\begin{tabular}{cccccc}
\hline Cluster & Size & Silhouette & Mean (Year) & Theme & Alternative Themes \\
\hline 0 & 96 & 0.886 & 2008 & Cost overruns & $\begin{array}{c}\text { Transportation } \\
\text { infrastructure project }\end{array}$ \\
\hline 1 & 59 & 0.825 & 2010 & $\begin{array}{c}\text { Quantitative spatial } \\
\text { economics }\end{array}$ & $\begin{array}{c}\text { Infrastructure spatial } \\
\text { framework }\end{array}$ \\
\hline 2 & 57 & 0.976 & 2009 & $\begin{array}{c}\text { Prioritizing highway } \\
\text { defragmentation location }\end{array}$ & Impacts approach \\
\hline 3 & 55 & 0.762 & 2007 & Local development & Public transport investment \\
\hline 4 & 54 & 0.91 & 2012 & Land value & Property value \\
\hline 5 & 52 & 0.903 & 2008 & Regional economic growth & Regional economic growth \\
\hline
\end{tabular}

\subsection{Hierarchy Analysis of Key Concepts}

The co-citation network above was divided into 174 co-citation clusters. These clusters were labeled by index terms from their own citers. These keywords show the most representative research topics related to transportation infrastructure. The left part of Figure 12 shows the word cloud based on cluster labels filtered by the same or similar labels of clusters. In this figure, the keyword size represents the frequency of cluster labels. It is clear that the main research topics include economic, region or urban development and spatial effect analysis. However, the cluster data only analyzed the label information, and did not identify other potentially relevant information. Therefore, a report of automatically generated narratives was used to analyze the word cloud distribution further, as shown in the right part of Figure 12. The narratives include the main subjects in the titles and abstracts of the top references in the top 62 clusters that are relatively complete. We can see that hot research topics consist of urban development, project, economic, cost and policies. In particular, we identified 
some potential topics that were excluded in the left graph, such as land, risk, panel data and policies. By means of the two-step summary, potential keywords could be easily identified.
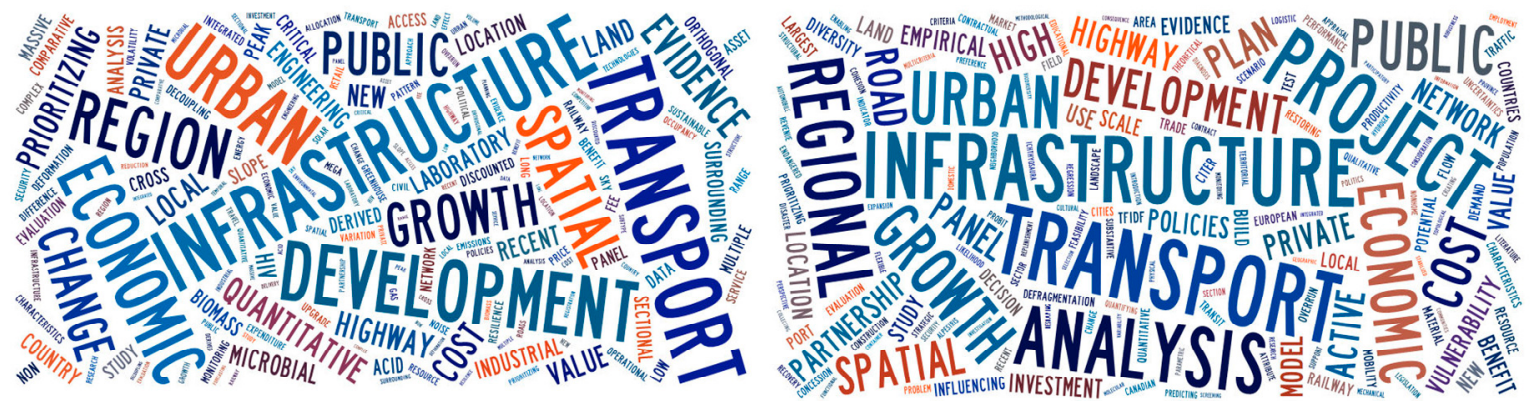

Figure 12. Word cloud distribution of co-citation cluster results. (Tool: Tagxedo (www.tagxedo.com). Data source: Labels of the top 62 clusters, narrative summary report of the co-citation network.)

Additionally, key concepts identified from the titles of citing articles in Cluster \#0 were algorithmically organized according to hierarchical relations derived from co-occurring concepts. Figure 13 shows the main concept tree of Cluster \#0. The largest branch of such a hierarchy typically reflects the main concepts of scholarly publications produced by the specialty behind the cluster. The main logical categories include transport infrastructure, projects, cost overruns and impact. The category "Transportation Infrastructure" mainly focuses on improving the project performance separately from the traditional and important problem "Cost Overrun". In particular, the category "impact" emerged gradually as an independent branch, which was driven by the increasing quantity and complexity of transportation infrastructure. It is notable that the transportation infrastructure branch highlights the characteristics (large, resilience, spatial and complexity), research methods (modeling, econometric and network mapping) and research questions (quality, risk, performance and PPP). In other words, sub-categories in this figure indicate the characteristics, questions, objects, dimensions and methods related to transportation infrastructure. The identity of category labels based on the title data obeys the logical tree algorithm of the software Citespace. This figure not only shows the main research topics but the logical relationships among these topics.

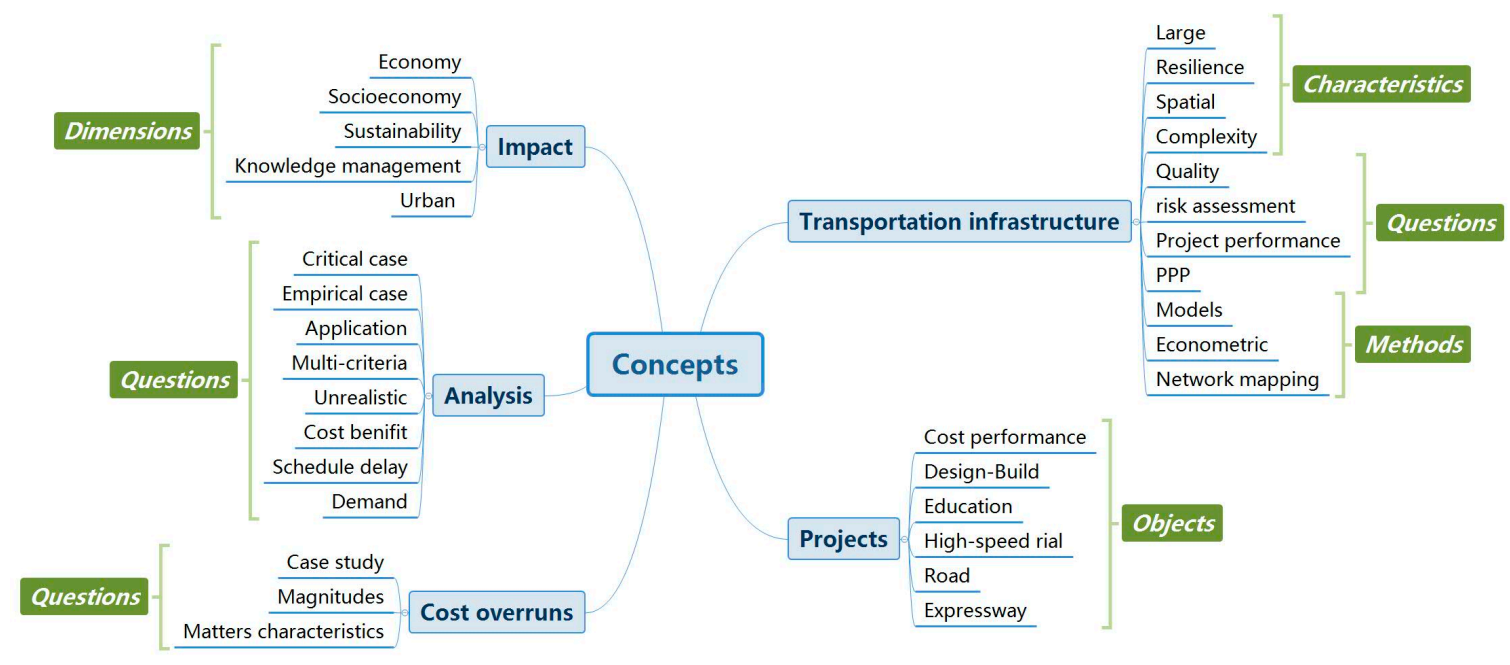

Figure 13. A hierarchy of key concepts in Cluster \#0.

To understand the hierarchy better, the key concepts in the top 7 Clusters (\#0-\#6) were identified in one hierarchy. Figure 14 summarizes the concept tree generated by Citespace according to the reference 
titles in Cluster \#0-\#6. The categories colored blue were identified automatically. For the systematic expression of the hierarchy, some branches colored green are used to conclude the fragmented research questions. In addition, this hierarchy filtered the repeating keywords and deleted words which cannot indicate the main research questions, such as "analysis". However, the sub-category concepts of the branch "analysis" were distributed in other branches. Meanwhile, some sub-categories of the branch "transportation infrastructure" were distributed in the summative branches such as the "objects" and "methods". We can see from Figure 14 that the main branch is "impacts", in which the "spillover effects" and "countries" are listed separately. This means the topic of spillover effect is the intensive research issue, and there are many countries analyzing the impacts of transportation infrastructure on the national scale. In addition, the "impact" category summarized some detailed topics such as land use, urban development and spatial effect. Compared with Figure 13, this hierarchy identified more specific topics, such as rail and road research. Although the amount of data in Figure 14 is about seven times greater than in Figure 13, the hierarchy framework becomes more clear and systematic after filtering out repeated data. More importantly, this systematic hierarchy can help to identify the hottest and most representative research issues quickly.

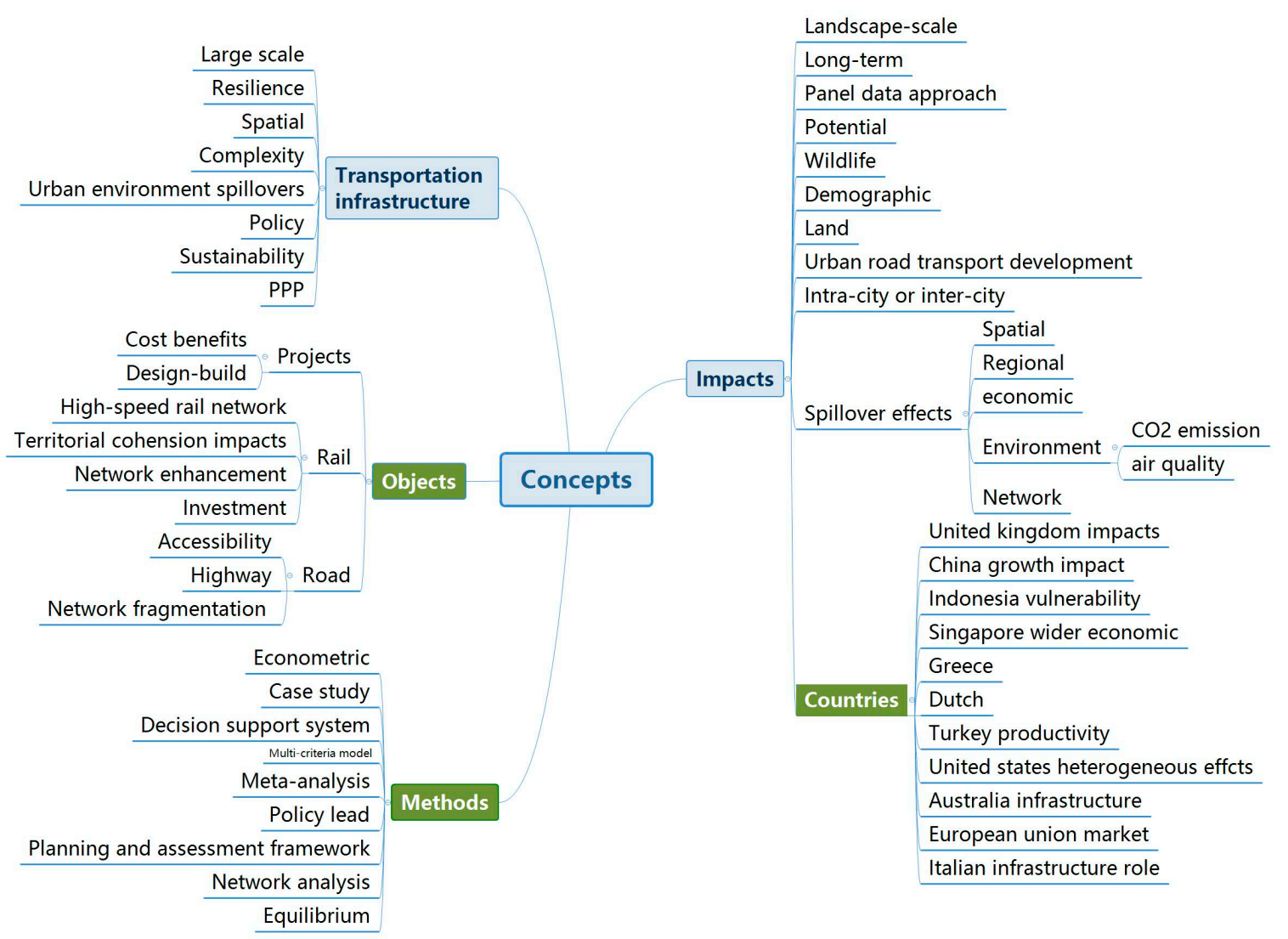

Figure 14. A hierarchy of key concepts in Cluster \#0-\#6.

\section{Conclusions}

This scientometric review based on over 2500 publications from 2000 to 2017 presented the systematic knowledge structure related to impacts of transportation infrastructure on sustainable development. Due to the complex impact mechanism, the identification process needs an in-depth understanding and clear expression. Although reviews related to transportation infrastructure have received attention, the scientometric review with visual expression provides a better way to explore the potential information hidden in knowledge network compared with the traditional review. In this paper, the presentation of scientometric and systematic reviews includes four main steps. Firstly, 
co-author analysis was used to identify the highly productive authors, institutions and countries to show the overall research status. Then, the co-occurring analysis was used to identify and visualize the overall research trends based on discipline and keyword information. Next, citing articles and cited references were modulated to find co-citation relationships and modularity labels by timeline visualization. Finally, after the modularity, the cluster information was analyzed further to conclude the hierarchy concepts of the main clusters, which accurately identified key points. These four steps analyzed the research status and emerging trends of transportation infrastructure's impacts on sustainable development from multiple perspectives, such as author information, collaborative relationships and reference relationships. In addition, compared with the traditional literature review, this scientometric analysis shows the representative information clearly based on a visual map. Importantly, this visual expression provides an easier way to understand the complex collaboration network of literature.

The main research findings are as follows. First, collaboration links among the most productive authors were more frequent than other authors. Moreover, the productive authors generally led to modularity. Second, institutions with high centrality play important roles in the institution network, such as Delft University of Technology, University of Illinois and Georgia Institute of Technology. In addition, countries occupying key positions include USA, England and China. Third, the hot topics related to transportation infrastructure include cost, performance, quality and investment issues from the project level. In addition, from a more macro perspective, economic, social and environmental effects of transportation infrastructure were all caught. Fourth, according to the hierarchy analysis, specific research objects, methods and multiple effects of transportation infrastructure were identified. It is noticeable that spillover effects of transportation infrastructure include some dependent sub-categories, such as spatial, regional, economic and environmental effects. These more macro keywords indicate the complexity of impact mechanisms. In addition, transportation infrastructure has huge impacts on land, urban development, human life and city networks.

However, there are also some limitations that need further improvement in this study. A limitation of using bibliographic databases is that the WOS lacks the information of books and reports in public sources, thus necessitating the integration of multiple data resources. In addition, due to the limitations of the analysis tool, our study could not analyze the information hidden in the references' context. Additionally, the determination of search keywords mainly relies on the subjective judgment of the authors, which might lead to data being missing or incomplete. Given these limitations, multiple analysis was exerted in this work to make up for the data limitations. In this study, the titles, keywords and abstracts could be credibly representative of the main context. Our findings not only reveal research trends, but future research directions. In the future, two directions-integrated study of various spillover effects and network effects of mega transportation infrastructures such as railway and road-will be valuable research issues. By conducting further research in these directions, an improved understanding of the significance of the transportation infrastructure will be obtained, and the planning of transport networks will be conducted under proper advice. In conclusion, this study provides valuable information for both researchers and practitioners to understand the significant and complex impact of transportation infrastructure. It is clear that in both technological issues and management issues, the impact assessment is the key step to justifying the research in the field of transportation infrastructure. This scientometric review will lead to the construction of a theoretical framework to guide this practice.

Author Contributions: Luqi Wang and Xiaolong Xue contributed to the conceptualization and methodology. Luqi Wang and Zebin Zhao analyzed the data and results. Luqi Wang and Zeyu Wang wrote and edited the draft. Xiaolong Xue and Zebin Zhao contributed to the project administration and funding acquisition.

Acknowledgments: This work was funded by the National Natural Science Foundation of China (NSFC) (Grant No. 71390522, No. 71671053, No. 71271065, No. 71771067). This research was also supported by the National Key R\&D Program of China (No. 2016YFC0701800 and No. 2016YFC0701808).

Conflicts of Interest: The authors declare no conflict of interest. 


\section{Appendix A}

\begin{tabular}{|c|c|c|c|c|c|}
\hline ID & Label & ID & Label & ID & Label \\
\hline 0 & Cost overrun & 21 & Cross-sectional study & 42 & $\begin{array}{l}\text { Forecasting infrastructure } \\
\text { resilience }\end{array}$ \\
\hline 1 & $\begin{array}{c}\text { Quantitative } \\
\text { spatial economics }\end{array}$ & 22 & Spatial structure & 43 & Price-difference approach \\
\hline 2 & $\begin{array}{c}\text { Prioritizing } \\
\text { highway } \\
\text { defragmentation }\end{array}$ & 23 & $\begin{array}{l}\text { Critical transportation } \\
\text { infrastructure }\end{array}$ & 44 & Sustainable development \\
\hline 3 & Local development & 24 & Panel data evidence & 45 & Retail travel pattern \\
\hline 4 & Land value & 25 & $\begin{array}{l}\text { Massive non-orthogonal } \\
\text { multiple access }\end{array}$ & 46 & Traveler characteristics \\
\hline 5 & $\begin{array}{l}\text { Regional economic } \\
\text { growth }\end{array}$ & 26 & Low-volume roads & 47 & Operational effect \\
\hline 6 & $\begin{array}{l}\text { New transport } \\
\text { infrastructure }\end{array}$ & 27 & $\begin{array}{l}\text { Planning transport } \\
\text { infrastructure }\end{array}$ & 48 & Noise reduction \\
\hline 7 & $\begin{array}{l}\text { Public-private } \\
\text { partnership }\end{array}$ & 28 & Comparative evaluation & 49 & Changing transport system \\
\hline 8 & $\begin{array}{l}\text { Infrastructure } \\
\text { change region }\end{array}$ & 29 & $\begin{array}{c}\text { Transportation } \\
\text { infrastructure asset }\end{array}$ & 50 & $\begin{array}{c}\text { Mega region economic } \\
\text { development }\end{array}$ \\
\hline 9 & $\begin{array}{l}\text { Recent laboratory } \\
\text { research }\end{array}$ & 30 & Temporal effect & 51 & $\begin{array}{c}\text { Civil infrastructure security } \\
\text { upgrade }\end{array}$ \\
\hline 10 & $\begin{array}{l}\text { Microbial } \\
\text { engineering }\end{array}$ & 31 & Infrastructure network & 52 & Political volatility \\
\hline 11 & hiv-1 subtype & 32 & $\begin{array}{l}\text { Discounted registration } \\
\text { fee }\end{array}$ & 53 & $\begin{array}{l}\text { Greenhouse gas emissions } \\
\text { reduction }\end{array}$ \\
\hline 12 & Industrial location & 33 & Environmental benefit & 54 & Spatiotemporal variation \\
\hline 11 & $\begin{array}{l}\text { Developing-country } \\
\text { analysis }\end{array}$ & 34 & Service delivery & 55 & $\begin{array}{c}\text { Transportation infrastructure } \\
\text { expenditure }\end{array}$ \\
\hline 14 & Urban growth & 35 & Competitive sky & 56 & Resource allocation \\
\hline 15 & $\begin{array}{l}\text { Road transport } \\
\text { technologies }\end{array}$ & 36 & $\begin{array}{l}\mathrm{CO}_{2} \text { transport } \\
\text { technologies }\end{array}$ & 57 & $\begin{array}{c}\text { Transport infrastructure } \\
\text { investment }\end{array}$ \\
\hline 16 & Peak travel & 37 & Railway infrastructure & 58 & Transport policies \\
\hline 17 & Urban surrounding & 38 & $\begin{array}{l}\text { Long-range } \\
\text { transportation }\end{array}$ & 59 & International evidence \\
\hline 18 & $\begin{array}{l}\text { biomass-derived } \\
\text { acid }\end{array}$ & 39 & $\begin{array}{l}\text { Decoupling urban } \\
\text { transport }\end{array}$ & 60 & Occupancy model \\
\hline 19 & $\begin{array}{c}\text { Transport } \\
\text { infrastructure } \\
\text { development }\end{array}$ & 40 & $\begin{array}{c}\text { Complex urban } \\
\text { infrastructure } \\
\text { deformation monitoring }\end{array}$ & 61 & Solar energy \\
\hline 20 & $\begin{array}{c}\text { transport } \\
\text { infrastructure slope }\end{array}$ & 41 & Integrated approach & 62 & Public investment research \\
\hline
\end{tabular}




\section{Appendix B}

\begin{tabular}{|c|c|c|}
\hline ID & Label & Most Active Citer \\
\hline 0 & Cost overrun & $\begin{array}{l}\text { Cantarelli, C.C. (2010) cost overruns in large-scale transportation infrastructure } \\
\text { projects: explanations and their theoretical embeddedness }\end{array}$ \\
\hline 1 & $\begin{array}{l}\text { Quantitative spatial } \\
\text { economics }\end{array}$ & Redding, S.J. (2017) quantitative spatial economics \\
\hline 2 & $\begin{array}{l}\text { Prioritizing highway } \\
\text { defragmentation }\end{array}$ & $\begin{array}{l}\text { Gurrutxaga, M. (2014) prioritizing highway defragmentation locations for } \\
\text { restoring landscape connectivity. }\end{array}$ \\
\hline 3 & Local development & $\begin{array}{l}\text { Gutierrez, J. (2010) using accessibility indicators and gis to assess spatial } \\
\text { spillovers of transport infrastructure investment. }\end{array}$ \\
\hline 4 & Land value & $\begin{array}{l}\text { Brey, R. (2017) is the widespread use of urban land for cycling promotion policies } \\
\text { cost effective? A cost-benefit analysis of the case of seville. }\end{array}$ \\
\hline 5 & Regional economic growth & $\begin{array}{l}\text { Deng, T.T. (2013) impacts of transport infrastructure on productivity and } \\
\text { economic growth: recent advances and research challenges. }\end{array}$ \\
\hline 6 & $\begin{array}{l}\text { New transport } \\
\text { infrastructure }\end{array}$ & $\begin{array}{l}\text { Ogilvie, D. (2010) commuting and health in cambridge: a study of a 'natural } \\
\text { experiment' in the provision of new transport infrastructure. }\end{array}$ \\
\hline 7 & Public-private partnership & $\begin{array}{l}\text { Sarmento, J.M. (2016) anatomy of public-private partnerships: their creation, } \\
\text { financing and renegotiations. }\end{array}$ \\
\hline 8 & $\begin{array}{l}\text { Infrastructure change } \\
\text { region }\end{array}$ & $\begin{array}{l}\text { Chen, C.L. (2017) can transport infrastructure change regions' economic } \\
\text { fortunes? Some evidence from Europe and China. }\end{array}$ \\
\hline 9 & Recent laboratory research & $\begin{array}{l}\text { Butler, E. (2011) a review of recent laboratory research and commercial } \\
\text { developments in fast pyrolysis and upgrading. }\end{array}$ \\
\hline 10 & Microbial engineering & $\begin{array}{l}\text { Peralta-Yahya, P.P. (2012) microbial engineering for the production of advanced } \\
\text { biofuels. }\end{array}$ \\
\hline 11 & hiv-1 subtype & $\begin{array}{l}\text { Tatem, A.J. (2012) spatial accessibility and the spread of hiv-1 subtypes and } \\
\text { recombinants. }\end{array}$ \\
\hline 12 & Industrial location & $\begin{array}{l}\text { Arauzo-Carod, J.M. (2013) location determinants of new firms: does skill level of } \\
\text { human capital really matter? }\end{array}$ \\
\hline 11 & $\begin{array}{l}\text { Developing-country } \\
\text { analysis }\end{array}$ & $\begin{array}{l}\text { Fare, R. (2009) optimal investment in transportation infrastructure when } \\
\text { middlemen have market power: a developing-country analysis. }\end{array}$ \\
\hline 14 & Urban growth & $\begin{array}{l}\text { Aljoufie, M. (2013) urban growth and transport infrastructure interaction in } \\
\text { jeddah between } 1980 \text { and } 2007 .\end{array}$ \\
\hline 15 & $\begin{array}{l}\text { Road transport } \\
\text { technologies }\end{array}$ & Streimikiene, D. (2013) comparative assessment of road transport technologies. \\
\hline 16 & Peak travel & $\begin{array}{l}\text { Garceau, T.J. (2014) peak travel and the decoupling of vehicle travel from the } \\
\text { economy a synthesis of the literature. }\end{array}$ \\
\hline 17 & Urban surrounding & $\begin{array}{l}\text { Chatziioannou, I. (2017) evaluation of the urban transportation infrastructure } \\
\text { and its urban surroundings in the iztapalapa county: a geotechnology approach } \\
\text { about its management. }\end{array}$ \\
\hline 18 & biomass-derived acid & $\begin{array}{l}\text { Serrano-Ruiz, J.C. (2012) catalytic transformations of biomass-derived acids into } \\
\text { advanced biofuels. }\end{array}$ \\
\hline 19 & $\begin{array}{l}\text { Transport infrastructure } \\
\text { development }\end{array}$ & $\begin{array}{l}\text { De Jong, M. (2012) the pros and cons of confucian values in transport } \\
\text { infrastructure development in China. }\end{array}$ \\
\hline 20 & $\begin{array}{l}\text { transport infrastructure } \\
\text { slope }\end{array}$ & $\begin{array}{l}\text { Smethurst, J.A. (2017) current and future role of instrumentation and monitoring } \\
\text { in the performance of transport infrastructure slopes. }\end{array}$ \\
\hline
\end{tabular}


Appendix C. High-Impact Number in Top 10 Clusters

\begin{tabular}{|c|c|c|c|c|c|}
\hline Clusters & Year & Authors & Clusters & Year & Authors \\
\hline \multirow{9}{*}{$\begin{array}{l}\text { \#0 Cost } \\
\text { overrun }\end{array}$} & \multirow{3}{*}{2008} & Priemus H & \multirow{9}{*}{$\begin{array}{c}\text { \#3 Local } \\
\text { development }\end{array}$} & \multirow{3}{*}{2008} & Weisbrod G \\
\hline & & Banister D & & & Crescenzi R \\
\hline & & Khadaroo J & & & Lopez E \\
\hline & & Dimitriou HT & & \multirow{3}{*}{2010} & Lopez E \\
\hline & 2010 & Tang LY & & & Brocker J \\
\hline & & Cantarelli CC & & & Gutierrez J \\
\hline & \multirow{3}{*}{2012} & Beukers E & & \multirow{3}{*}{2012} & Nensher DA \\
\hline & & Cantarelli CC & & & Levinson DM \\
\hline & & Cantarelli CC & & & Crescenzi R \\
\hline \multirow{9}{*}{$\begin{array}{c}\text { \#1 Quantitative } \\
\text { spatial } \\
\text { economics }\end{array}$} & \multirow{3}{*}{2012} & Koopmans C & \multirow{9}{*}{ \#4 Land value } & \multirow{3}{*}{2013} & Nakagawa S \\
\hline & & Banerjee A & & & Mchammad SI \\
\hline & & Duranton G & & & Melo PC \\
\hline & \multirow{3}{*}{2007} & Baird AJ & & \multirow{3}{*}{2010} & Percoco M \\
\hline & & Wagner J & & & Cohen JP \\
\hline & & Baum-snow N & & & Munoz-Raskin R \\
\hline & & Kline P & & \multirow{3}{*}{2015} & Bensassi S \\
\hline & 2014 & Duranton G & & & Mattsson LG \\
\hline & & Faber B & & & Reggiani A \\
\hline \multirow{8}{*}{$\begin{array}{l}\text { \#2 Prioritizing } \\
\text { highway } \\
\text { defragmentation } \\
\text { location }\end{array}$} & & Balkenhol N & \multirow{8}{*}{$\begin{array}{l}\# 5 \text { regional } \\
\text { economic }\end{array}$} & \multirow{3}{*}{2011} & Banister D \\
\hline & 2009 & Glista DJ & & & Hong JJ \\
\hline & & Fahrig L & & & Lakshmanan TR \\
\hline & \multirow{3}{*}{2010} & Landguth EL & & \multirow{3}{*}{2009} & Jiwattanakulpaisarn $\mathrm{P}$ \\
\hline & & Benitez-Lopez A & & & Bronzini R \\
\hline & & Holderogger R & & & Lesage J \\
\hline & \multirow{2}{*}{2012} & Zeller KA & & \multirow{2}{*}{2013} & Na ky \\
\hline & & Hepenstrick D & & & Yu NN \\
\hline
\end{tabular}

\section{References}

1. Rodrigue, J.-P.; Comtois, C.; Slack, B. The Geography of Transport Systems; Taylor \& Francis: Abingdon, UK, 2016.

2. Liu, J.; Mooney, H.; Hull, V.; Davis, S.J; Gaskell, J.; Hertel, T.; Lubchenco, J.; Seto, K.C.; Gleick, P.; Kremen, C.; et al. Systems integration for global sustainability. Science 2015, 347, 1258832. [CrossRef] [PubMed]

3. Kammen, D.M.; Sunter, D.A. City-integrated renewable energy for urban sustainability. Science 2016, 352, 922-928. [CrossRef] [PubMed]

4. Jiang, X.; Zhang, L.; Xiong, C.; Wang, R. Transportation and regional economic development: Analysis of spatial spillovers in china provincial regions. Netw. Spat. Econ. 2016, 16, 769-790. [CrossRef]

5. Chen, Z.; Haynes, K.E. Transportation infrastructure and economic growth in china: A meta-analysis. In Socioeconomic Environmental Policies and Evaluations in Regional Science; Springer: Berlin, Germany, 2017; pp. 339-357.

6. Doyle, M.W.; Havlick, D.G. Infrastructure and the environment. Annu. Rev. Environ. Resour. 2009, 34, 349-373. [CrossRef]

7. Tasic, I.; Porter, R.J. Modeling spatial relationships between multimodal transportation infrastructure and traffic safety outcomes in urban environments. Saf. Sci. 2016, 82, 325-337. [CrossRef]

8. Camp, J.; Abkowitz, M.; Hornberger, G.; Benneyworth, L.; Banks, J.C. Climate change and freight-transportation infrastructure: Current challenges for adaptation. J. Infrastruct. Syst. 2013, 19, 363-370. [CrossRef] 
9. Müller, D.B.; Liu, G.; Løvik, A.N.; Modaresi, R.; Pauliuk, S.; Steinhoff, F.S.; Brattebø, H. Carbon emissions of infrastructure development. Environ. Sci. Technol. 2013, 47, 11739-11746. [CrossRef] [PubMed]

10. Laurance, W.F.; Cochrane, M.A.; Bergen, S.; Fearnside, P.M.; Delamônica, P.; Barber, C.; D'angelo, S.; Fernandes, T. The future of the Brazilian Amazon. Science 2001, 291, 438-439. [CrossRef] [PubMed]

11. Laurance, W.F.; Goosem, M.; Laurance, S.G. Impacts of roads and linear clearings on tropical forests. Trends Ecol. Evol. 2009, 24, 659-669. [CrossRef] [PubMed]

12. Cohen, J.P. The broader effects of transportation infrastructure: Spatial econometrics and productivity approaches. Transp. Res. Part E Logist. Transp. Rev. 2010, 46, 317-326. [CrossRef]

13. Cantos, P.; Gumbau-Albert, M.; Maudos, J. Transport infrastructures, spillover effects and regional growth: Evidence of the Spanish case. Transp. Rev. 2005, 25, 25-50. [CrossRef]

14. Ming, Y.T.; Yi, J.L. Scientometric analysis of transport phenomenon literature, 1900-2007. Malays. J. Libr. Inf. Sci. 2009, 14, 35-58.

15. Heilig, L.; Voss, S. A scientometric analysis of public transport research. J. Public Transp. 2015, 18, $111-141$. [CrossRef]

16. Holl, A. Manufacturing location and impacts of road transport infrastructure: Empirical evidence from Spain. Reg. Sci. Urban Econ. 2004, 34, 341-363. [CrossRef]

17. Correia, A.G.; Winter, M.G.; Puppala, A.J. A review of sustainable approaches in transport infrastructure geotechnics. Transp. Geotech. 2016, 7, 21-28. [CrossRef]

18. Durango-Cohen, P.L.; Sarutipand, P. Capturing interdependencies and heterogeneity in the management of multifacility transportation infrastructure systems. J. Infrastruct. Syst. 2007, 13, 115-123. [CrossRef]

19. Grimsey, D.; Lewis, M.K. Evaluating the risks of public private partnerships for infrastructure projects. Int. J. Proj. Manag. 2002, 20, 107-118. [CrossRef]

20. Flyvbjerg, B. What you should know about megaprojects and why: An overview. Proj. Manag. J. 2014, 45, 6-19. [CrossRef]

21. Flyvbjerg, B. The Oxford Handbook of Megaproject Management; Oxford University Press: Oxford, UK, 2017.

22. Lakshmanan, T.R. The broader economic consequences of transport infrastructure investments. J. Transp. Geogr. 2011, 19, 1-12. [CrossRef]

23. Achour, H.; Belloumi, M. Investigating the causal relationship between transport infrastructure, transport energy consumption and economic growth in Tunisia. Renew. Sustain. Energy Rev. 2016, 56, 988-998. [CrossRef]

24. Banister, D.; Berechman, Y. Transport investment and the promotion of economic growth. J. Transp. Geogr. 2001, 9, 209-218. [CrossRef]

25. Paul, S. Effects of public infrastructure on cost structure and productivity in the private sector. Econ. Rec. 2003, 79, 446-461. [CrossRef]

26. Youngson, A.J. Britain's Economic Growth 1920-1966; Routledge: Abingdon, UK, 2013.

27. Ni, P.; Kamiya, M.; Ding, R. Cities Network along the Silk Road: The Global Urban Competitiveness Report 2017; Springer: Singapore, 2017.

28. Muller, M.; Biswas, A.; Martin-Hurtado, R.; Tortajada, C. Built infrastructure is essential. Science 2015, 349, 585-586. [CrossRef] [PubMed]

29. Laurance, W.F.; Clements, G.R.; Sloan, S.; O'connell, C.S.; Mueller, N.D.; Goosem, M.; Venter, O.; Edwards, D.P.; Phalan, B.; Balmford, A. A global strategy for road building. Nature 2014, 513, $229-232$. [CrossRef] [PubMed]

30. Meng, F.; Fan, L.; Zhou, P.; Zhou, D. Measuring environmental performance in China's industrial sectors with non-radial dea. Math. Comput. Model. 2013, 58, 1047-1056. [CrossRef]

31. Nilsson, C.; Reidy, C.A.; Dynesius, M.; Revenga, C. Fragmentation and flow regulation of the world's large river systems. Science 2005, 308, 405-408. [CrossRef] [PubMed]

32. Palmer, M.A. Water resources: Beyond infrastructure. Nature 2010, 467, 534-535. [CrossRef] [PubMed]

33. Tullos, D. Assessing the influence of environmental impact assessments on science and policy: An analysis of the three gorges project. J. Environ. Manag. 2009, 90 (Suppl. 3), S208-S223. [CrossRef] [PubMed]

34. Dahiya, S.; Singh, B.; Gaur, S.; Garg, V.; Kushwaha, H. Analysis of groundwater quality using fuzzy synthetic evaluation. J. Hazard. Mater. 2007, 147, 938-946. [CrossRef] [PubMed] 
35. Pirrone, N.; Trombino, G.; Cinnirella, S.; Algieri, A.; Bendoricchio, G.; Palmeri, L. The Driver-Pressure-StateImpact-Response (DPSIR) approach for integrated catchment-coastal zone management: Preliminary application to the Po catchment-Adriatic sea coastal zone system. Reg. Environ. Chang. 2005, 5, 111-137. [CrossRef]

36. Strogen, B.; Horvath, A. Greenhouse gas emissions from the construction, manufacturing, operation, and maintenance of us distribution infrastructure for petroleum and biofuels. J. Infrastruct. Syst. 2012, 19, 371-383. [CrossRef]

37. Costanza, R.; d'Arge, R.; De Groot, R.; Farber, S.; Grasso, M.; Hannon, B.; Limburg, K.; Naeem, S.; O'neill, R.V.; Paruelo, J.; et al. The value of the world's ecosystem services and natural capital. Nature 1997, 387, 253-260. [CrossRef]

38. Matten, D.; Moon, J. "Implicit" and "explicit" CSR: A conceptual framework for a comparative understanding of corporate social responsibility. Acad. Manag. Rev. 2008, 33, 404-424. [CrossRef]

39. McWilliams, A.; Siegel, D. Corporate social responsibility: A theory of the firm perspective. Acad. Manag. Rev. 2001, 26, 117-127. [CrossRef]

40. Buchanan, J.M.; Stubblebine, W.C. Externality. In Classic Papers in Natural Resource Economics; Springer: Berlin, Germany, 1962; pp. 138-154.

41. Mendler, S.; Odell, W. The Hok Guidebook to Sustainable Design; John Wiley \& Sons: Hoboken, NJ, USA, 2000.

42. Rajak, S.; Parthiban, P.; Dhanalakshmi, R. Sustainable transportation systems performance evaluation using fuzzy logic. Ecol. Indic. 2016, 71, 503-513. [CrossRef]

43. Loo, B.P.Y.; Banister, D. Decoupling transport from economic growth: Extending the debate to include environmental and social externalities. J. Transp. Geogr. 2016, 57, 134-144. [CrossRef]

44. Griggs, D.; Stafford-Smith, M.; Gaffney, O.; Rockström, J.; Öhman, M.C.; Shyamsundar, P.; Steffen, W.; Glaser, G.; Kanie, N.; Noble, I. Policy: Sustainable development goals for people and planet. Nature 2013, 495, 305-307. [CrossRef] [PubMed]

45. Rotolo, D.; Rafols, I.; Hopkins, M.M.; Leydesdorff, L. Strategic intelligence on emerging technologies: Scientometric overlay mapping. J. Assoc. Inf. Sci. Technol. 2017, 68, 214-233. [CrossRef]

46. Fan, X.; Gao, Y.; Ma, B.; Xia, Z. Chinese academic contribution to burns: A comprehensive bibliometrics analysis from 1985 to 2014. Burns 2016, 42, 1463-1470. [CrossRef] [PubMed]

47. Pullannagari, D. Bibliography Data Mining and Data Visualization. Master's Thesis, San Jose State University, San Jose, CA, USA, 2008.

48. Van Meeteren, M.; Poorthuis, A.; Derudder, B.; Witlox, F. Pacifying babel's tower: A scientometric analysis of polycentricity in urban research. Urb. Stud. 2016, 53, 1278-1298. [CrossRef]

49. Pouris, A.; Pouris, A. Scientometrics of a pandemic: HIV/AIDS research in South Africa and the world. Scientometrics 2010, 86, 541-552. [CrossRef]

50. Song, J.; Zhang, H.; Dong, W. A review of emerging trends in global PPP research: Analysis and visualization. Scientometrics 2016, 107, 1111-1147. [CrossRef]

51. Keathley-Herring, H.; Van Aken, E.; Gonzalez-Aleu, F.; Deschamps, F.; Letens, G.; Orlandini, P.C. Assessing the maturity of a research area: Bibliometric review and proposed framework. Scientometrics 2016, 109, 927-951. [CrossRef]

52. Hjørland, B.; Albrechtsen, H. Toward a new horizon in information science: Domain-analysis. J. Assoc. Inf. Sci. Technol. 1995, 46, 400-425. [CrossRef]

53. Chen, C. Citespace II: Detecting and visualizing emerging trends and transient patterns in scientific literature. J. Assoc. Inf. Sci. Technol. 2006, 57, 359-377. [CrossRef]

54. Chen, C. Citespace: A Practical Guide for Mapping Scientific Literature; Nova Science Publishers, Incorporated: Hauppauge, NY, USA, 2016.

55. Zheng, X.; Le, Y.; Chan, A.P.; Hu, Y.; Li, Y. Review of the application of Social Network Analysis (SNA) in construction project management research. Int. J. Proj. Manag. 2016, 34, 1214-1225. [CrossRef]

56. White, H.D. Pathfinder networks and author cocitation analysis: A remapping of paradigmatic information scientists. J. Assoc. Inf. Sci. Technol. 2003, 54, 423-434. [CrossRef]

57. Chen, C.; Morris, S. In Visualizing evolving networks: Minimum spanning trees versus pathfinder networks. In Proceedings of the IEEE Symposium on Information Visualization (INFOVIS 2003), Seattle, WA, USA, 19-21 October 2003; pp. 67-74. 
58. Chen, C.; Leydesdorff, L. Patterns of connections and movements in dual-map overlays: A new method of publication portfolio analysis. J. Assoc. Inf. Sci. Technol. 2014, 65, 334-351. [CrossRef]

59. Small, H. Co-citation in the scientific literature: A new measure of the relationship between two documents. J. Assoc. Inf. Sci. Technol. 1973, 24, 265-269. [CrossRef]

60. Deerwester, S.; Dumais, S.T.; Furnas, G.W.; Landauer, T.K.; Harshman, R. Indexing by latent semantic analysis. J. Am. Soc. Inf. Sci. 1990, 41, 391. [CrossRef] 